\title{
West Virginia High School Guidance Counselors Perceptions and Interactions with Agricultural Education Programs in Their Schools
}

Nicole Riggle Shipman

West Virginia University

Follow this and additional works at: https://researchrepository.wvu.edu/etd

\section{Recommended Citation}

Shipman, Nicole Riggle, "West Virginia High School Guidance Counselors Perceptions and Interactions with Agricultural Education Programs in Their Schools" (2013). Graduate Theses, Dissertations, and Problem Reports. 3618.

https://researchrepository.wvu.edu/etd/3618

This Thesis is protected by copyright and/or related rights. It has been brought to you by the The Research Repository @WVU with permission from the rights-holder(s). You are free to use this Thesis in any way that is permitted by the copyright and related rights legislation that applies to your use. For other uses you must obtain permission from the rights-holder(s) directly, unless additional rights are indicated by a Creative Commons license in the record and/ or on the work itself. This Thesis has been accepted for inclusion in WVU Graduate Theses, Dissertations, and Problem Reports collection by an authorized administrator of The Research Repository @ WVU. For more information, please contact researchrepository@mail.wvu.edu. 
West Virginia High School Guidance Counselors Perceptions and Interactions with Agricultural Education Programs in Their Schools

\section{Nicole Riggle Shipman}

Thesis submitted to the

Davis College of Agriculture, Natural Resources and Design

at West Virginia University

in partial fulfillment of the requirements

for the degree of

\section{Master of Science}

in

Agricultural and Extension Education

Deborah A. Boone, Ph.D., Chair

Harry N. Boone, Jr., Ph.D.

Jean M. Woloshuk, Ed.D.

Division of Resource Management

Morgantown, West Virginia

2013

Keywords: agricultural education, guidance counselors 


\begin{abstract}
West Virginia High School Guidance Counselors Perceptions and Interactions with Agricultural Education Programs in Their Schools
\end{abstract}

\title{
Nicole Riggle Shipman
}

Guidance or vocational counselors have a strong influence over student placement in agricultural education programs. A descriptive research design using a mailed questionnaire was used for this study to determine methods used by West Virginia high school guidance counselors to determine student placement in agricultural education classes. The study found that a majority of the guidance counselors do not have an agricultural background. A majority of the counselors report enrolling students in agricultural programs regardless of their college or career goals. Counselors view agricultural teachers as concerned for students' achievement and personal growth and believe agricultural educators should be involved in scheduling students. While counselors are not fully aware of all facets of the agricultural program, they respect the agricultural instructors and the program. 


\section{DEDICATION}

To my Grandparents, without each of your influence, my education would never have been a possibility. Thank you, for keeping me green and growing all those years.

Mabel and Raymond Riggle

Richard and Dorothy Reynolds 


\section{ACKNOWLEDGEMENTS}

To Grandma Mabel who wanted to see me finish this, more than I did.

To my students who challenged me to make this happen.

To my family and friends thanks for your patience, love and laughter.

To the guidance counselors who inspired my curiosity.

To the women who just wouldn't let me quit.

Thank you.

Let it Grow! 


\section{TABLE OF CONTENTS}

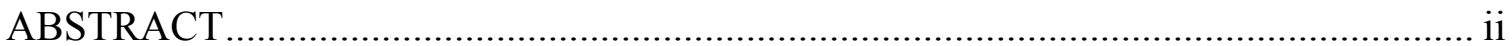

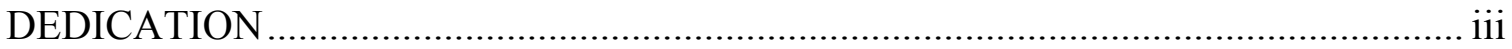

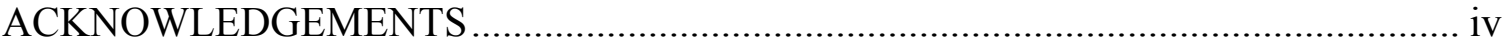

TABLE OF CONTENTS ..........................................................................................

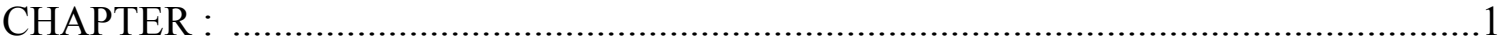

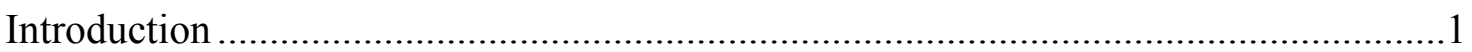

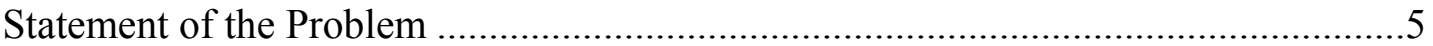

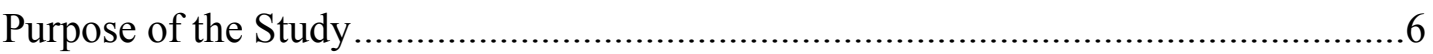

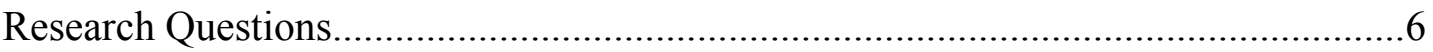

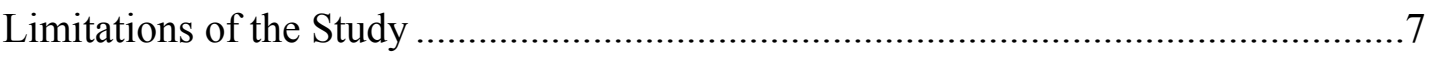

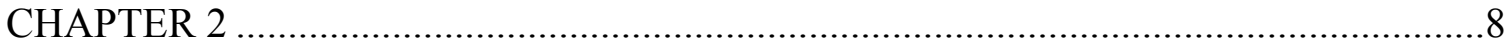

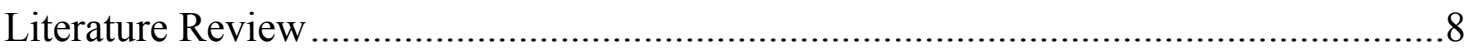

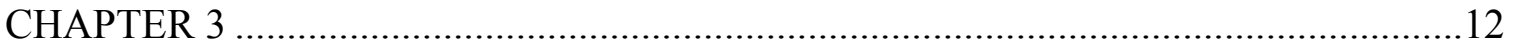

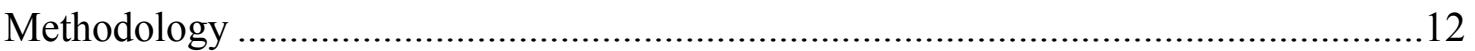

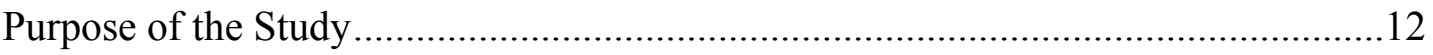

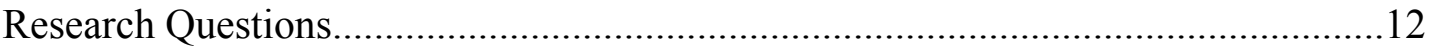

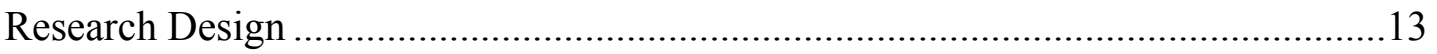

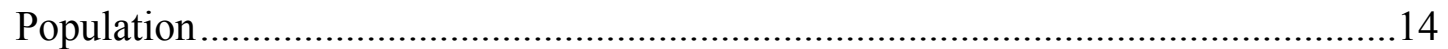

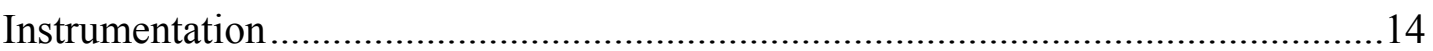

Data Collection Procedures .............................................................................15

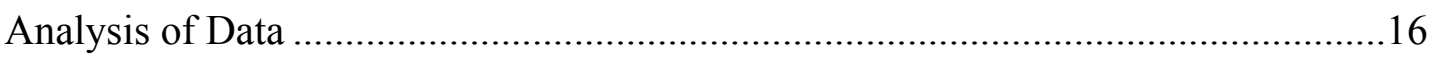

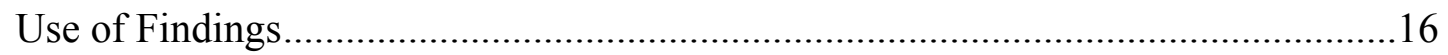


CHAPTER 4

Findings

Purpose of the Study.

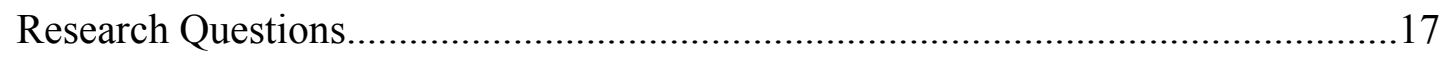

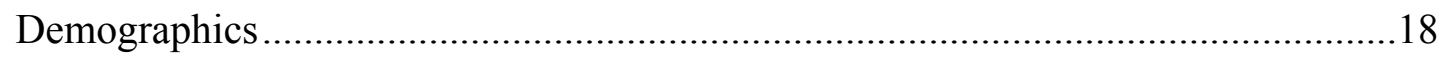

Guidance Counselors Perceptions of Agricultural Teachers .......................................32

Guidance Counselor's Perceptions of how the Agriculture Education

Programs Enrollment Affects Students

Guidance Counselors' Perceptions of How Students with IEP's Respond to

Career and Technical Education Programs Especially Agricultural Education

Guidance Counselors Perceptions of FFA Organization as it Pertains to the

Agricultural Curriculum

Counselor's Methods for Scheduling Students in Agricultural Classes.

Guidance Counselors Understanding of How They Affect Programs in Their

School

Guidance Counselors Understanding of Course Content and Requirements

Guidance Counselors' Perceptions of Students' Interest and Success ...

CHAPTER 5

Summary, Conclusions, and Recommendations ……….........................................52

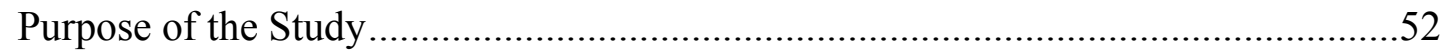

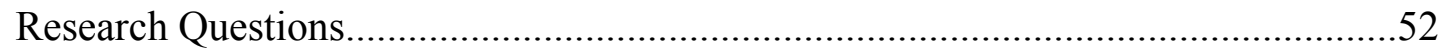

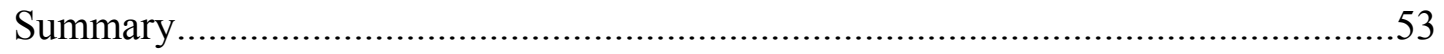

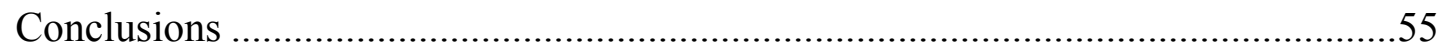

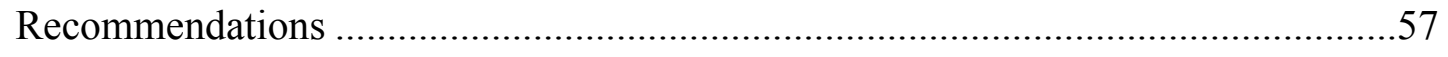

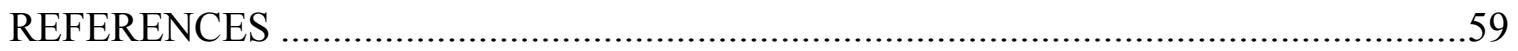




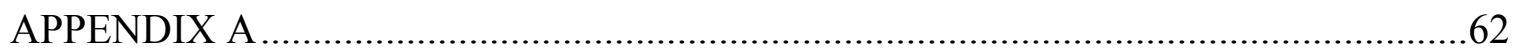

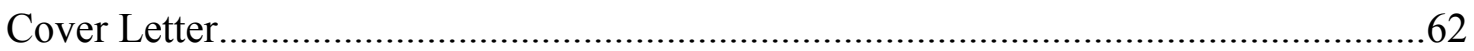

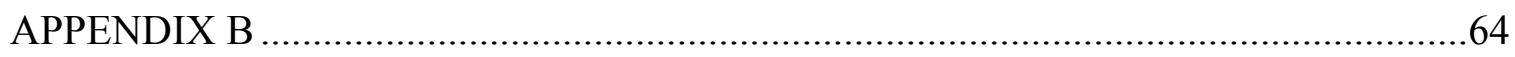

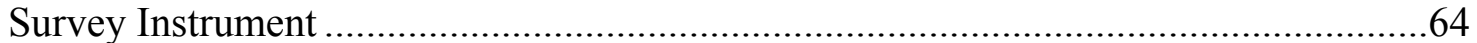




\section{LIST OF TABLES}

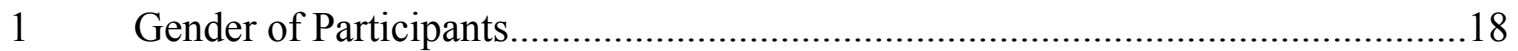

$2 \quad$ Years as a Guidance Counselor ................................................................... 19

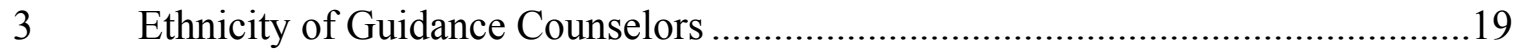

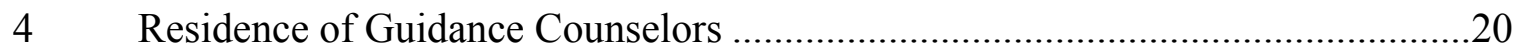

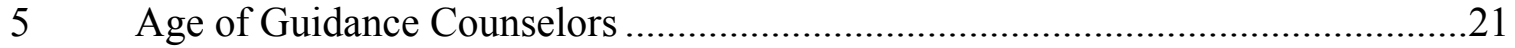

6 Guidance Counselors Enrolled in Agricultural Education during High

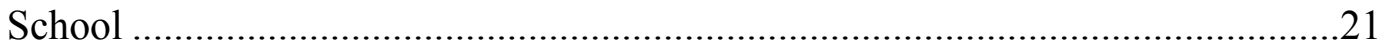

7 Guidance Counselors Who Were Members of 4-H as a Youth ............................22

$8 \quad$ Number of Individualized Education Plans per School ....................................23

9 Size of School Based on West Virginia Secondary School Athletic

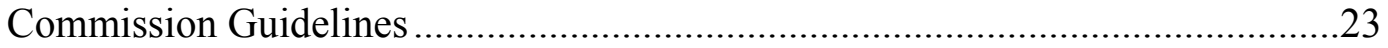

10 Agriculture Education Concentrations Offered ................................................24

11 Number of Agriculture Teachers in Each School ..........................................25

12 Counselors Ranking of the Most Important Reasons to Schedule Students in Agricultural Education Programs ..............................................................2

13 Counselors Ranking of Perceptions of Students with Individualized Education Plans Services for Academic Success...............................................29

14 Guidance Counselors Perceptions of Students Enrolled in Agricultural Education.

15 Guidance Counselors Perceptions of Agriculture Teachers ................................34

16 Guidance Counselor's Perceptions of How the Agriculture Education Programs Enrollment Affects Students.............................................................38

17 Guidance Counselors' Perceptions of How Students with IEP's Respond to Career and Technical Education Programs Especially Agricultural Education. 
18 Guidance Counselors Perceptions of FFA Organization as it Pertains to the

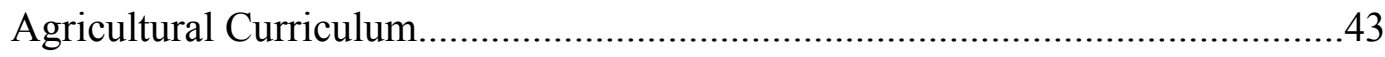

19 Counselor's Methods for Scheduling Students in Agricultural Classes................45

20 Guidance Counselors Understanding of How They Affect Programs in

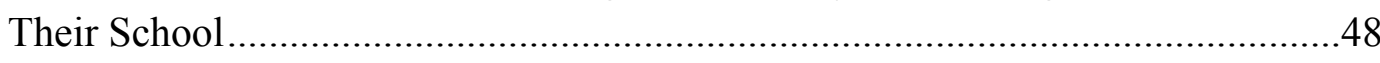

21 Guidance Counselors Understanding of Course Content and

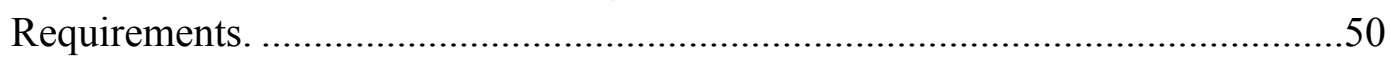

22 Guidance Counselors' Perceptions of Students' Interest and Success ..................51 


\section{CHAPTER 1}

\section{Introduction}

At the start of the $20^{\text {th }}$ century, farmers made up $38 \%$ of the labor force. There were 5.7 million farms, which averaged 147 acres of ground. As education changed, there was a greater push during this time period for farmers to increase production and become better educated on new practices that would enhance their farming production and allow them to become more diversified. Booker T. Washington using a mobile farm school began demonstrating new farming methods farmers could use to increase their farm yields. During this time period, the Roosevelt administration developed the Country Life Commission to help farm wives and to keep children on the farm. The emergence of Corn clubs and Seaman Knapp's boll weevil demonstration were the first works of extension education and paved the way for modern extension work and 4-H (Spielmaker, n.d.).

According to the 1910 Census, there were 12 million individuals participating in agriculture. The report noted that less than one percent had adequate training. In 1917 the United States Congress passed the Smith-Hughes Act to expand the concept of instruction of agriculture to high school students. This was the first act that authorized government control over a portion of the high school curriculum (Federal education policy, 2011). The Smith-Hughes Act was intended to promote vocational education that contained provisions for, agriculture education, home economics, and industry and trade training. The first 50 years of the Smith-Hughes Act, saw tremendous growth in vocational education. Before the law was passed, it was estimated that there were 200,000 vocational students who were receiving less than 3 million dollars in funding. 
Fifty years after the Smith-Hughes Act was implemented, 176 million dollars was budgeted annually for 3.4 million students. The Smith-Hughes Act provided funding for programs below the baccalaureate level, but above the age of 14 , and was targeted toward employment preparation. The law also provided funding for teacher training, and provided half of the vocational teacher's salaries. The Smith-Hughes Act promoted vocational education in public schools, but also served to separate vocational education from academic education in the high schools. The law provided for job specific skills but eliminated the need for theoretical and academic skills because the students were to receive no more than $50 \%$ academic instruction. This provision in the law is essentially, where the original separation of academic students and vocational students began (Patterson, n.d.).

The purpose to develop programming that adheres to the principles and ideals of the Smith Hughes Act has remained steadfast within agricultural education programs across America. Some components of the program have not been drastically altered since agricultural education helps students gain employment and succeed in these ever changing emotional and economical times. Agricultural educators are developing students' leadership skills coupled with career success and using these ideals as a strong motivating force regardless of their academic ability. Students are being encouraged and driven by the premise that agricultural education and many other career and technical education programs can acquire college course credit while still in high school. This change reflects how the agriculture industry has changed radically since the 1900s. In 1990 farmers made up only $2.6 \%$ of the workforce. Over half of the farms from 1950 no longer existed, less land overall was being farmed and farms went from representing $16 \%$ 
of the population to $1.8 \%$. The farm size however had grown to double the average size of 1950 farms, with the average farm size in 1990 being 473 acres. Land prices in 1990 were 10 times the value in 1950, averaging \$684 an acre, in the 1990 census report (University of Georgia Cooperative Extension Service, n.d.) Businesses were expanding and becoming more integrated with the rising technology of the day. The vertical integration of the farm is seeing higher production, which ultimately leads to commodity surpluses. Farmers are no longer the only job in agriculture. There is an increased focus on processors, shippers and marketing. Farmers have now begun to feed 100 people each. Farming begins to see the use of satellite technology to track and plan the farm. The biotechnology boom explodes new products in to the market that are weed and insect resistant. Agriculture is demonstrating a huge link to science and engineering to continue to meet the consumer demand (Spielmaker, n.d.)

In 1988 the National Research Council challenged the agricultural education profession to modify the objectives of high school agricultural education to include the teaching of science through agriculture and include teaching about agriculture (agricultural literacy). "Agriculture is too important of a topic to be taught only to a relatively small percentage of students considering careers in agriculture and pursuing vocational agricultural studies.”(National Research Council, 1988, p 1). Agricultural education should compliment academic studies and help every student make informed decisions with truth and knowledge by developing agricultural literacy. Agricultural education should begin in Kindergarten and continue through high school. It can be incorporated through existing courses. Production agriculture - farming is still dominating the curriculum and does not represent the jobs in the industry. The 
restrictions placed on programs falling under the confines of vocational education resonate the agriculture program only be for vocational purposes. Vocational agriculture programs must be upgraded to prepare students more effectively to move forward into college and pursue the career opportunities in biotechnology, agribusiness, and marketing. The curriculum must reflect a broader agenda (National Research Council, 1988).

For agriculture, students not only must know agriculture production but also be knowledgeable of the careers that depend on employees who have a working knowledge of agriculture. When the job outlook in other sectors of America's economy looks poor agriculture always seems to look up? In 2009 while other industries were reporting job losses agriculture had a $23 \%$ increase. These jobs were in all phases of agriculture including marketing and management, production and custom application (Schafer, 2011). This is a change from the inception of the Smith Hughes Act that stated that students should receive less then college education, and be prepared for an on farm career situation (Phipps \& Osborne, 1988).

High school guidance counselors play a vital role in assisting students with educated career choices. West Virginia Department of Education defines a school counselor as "A certified, highly-qualified, [minimum] master's-level professional counselor who addresses needs of all students in the areas of academic, career, personal/social development while at the same time, working collaboratively with educators, families, and the community." (West Virginia Department of Education, n.d. a). According to the American School Counselor Association, the role of the guidance counselor should be to provide students with services including individual student 
planning, responsive services to student issues and problems, programs and curriculum in developmental learning, system support and management. Individual student planning should include helping students to establish personal goals and begin the framework for their educational goals. Counselors should consult with parents, teachers and other educators to help student meet their immediate and future needs (American School Counselor Association, 2009). Because high school guidance counselors play such an important part in future career decisions, they must have adequate knowledge of all programs in their schools as well as any related careers. They can develop and foster this knowledge through attending inservices, attending professional meetings on a variety of topics, scheduling and attending career events for all students. The West Virginia Department of Education webpage for guidance counselors is a plethora of information on the curricula for counselors to use and teach students. There is no information on current courses and programs in West Virginia vocationally or academically, which demonstrates the states lack of coordination for adequate preparation of counselors in programs and student opportunities within their own schools (West Virginia Department of Education, n.d. b.)

\section{Statement of the Problem}

As student schedules are continually being tightened and are less adaptable because of increased credit requirements for graduation, guidance counselors are recommending that students choose programs besides agriculture (Thompson \& Russell, 1993). Agriculture teachers view guidance counselors as not understanding their program and its requirements. According to Bell and Fritz (1992) counseling services do 
not provide an awareness of career opportunities in agriculture. Many times agriculture teachers are concerned about why some students are placed in their programs and why others are not. Developing effective lines of communication between the school guidance counselors who help the students schedule and the diversity of programs being offered is critical.

\section{Purpose of the Study}

The purpose of this study was to determine the methods that guidance or vocational counselors in West Virginia public schools use to schedule students into agricultural education programs in their school. This study will help teachers understand how guidance counselors schedule students and help diffuse the perceptions that counselors do not value agricultural education program. By understanding what factors impact student placement in career and technical education programs by guidance counselors and how to better create channels of communications between the counselors and the teachers.

\section{Research Questions}

The following research questions were used to guide the study:

1. What criteria determines student placement in career and technical education programs?

2. How do you determine which students will be placed in each career and technical education program?

3. Are Individualized Education Plans (IEPs) for Special Needs students reviewed by counselors to determine which career and technical education program would best suit the student? 
4. What characteristics make career and technical education popular choices with students in West Virginia?

5. Does completer's certification or EDGE credits make a difference in scheduling students?

6. How much does a guidance counselor understand about career and technical education funding and guidelines?

\section{Limitations of the Study}

This study was limited to high school guidance counselors employed in West Virginia during the school year 2008 - 2009 that worked in a school that offered agricultural education programs. 


\section{CHAPTER 2}

\section{Literature Review}

As America becomes more of a global market place students exiting high school must leave with more skills than students 10 years ago. No longer should schools solely be focused on teaching the basics of reading, writing and arithmetic. They also must develop student's ability to use technology, adapt to change, develop peer tolerance skills and encourage them to become lifelong learners (Feller, 1994). By viewing counselors and parents as potential collaborators in developing students' course selections and career planning, teachers can develop allies in helping develop an appropriate academic plan for effectively serving each student (Thompson, 1993).

Counselors should promote the idea that vocational education is better supported when it is paired with a supporting academic program of study. The two cannot be considered to be competing programs of study. They must work in collaboration to develop students who can succeed in today's ever changing work requirements (Feller, 1994). By developing comprehensive counseling departments Fuller (1994) believes that counselors can assure that every student regardless of their achievement level, or career plans can receive skills that can be found in both academia and vocational courses. Secretary of Education Arne Duncan in a 2010 speech to the College AP Board stated that school counselors should be the leading advocates for college or career readiness counseling although this is not the case when nationwide there is trend of too many students assigned to each counselor (Reese, 2010). Counselors' relationships with students can be the students' final push toward a particular career and technical program that plays a vital role in the success of each student and more importantly the success of 
the program. Closer ties with the counselors are essential in effective marketing of one's program (Thompson, 1993).

Agricultural programs have made tremendous strides in developing new and effective programming but there is still an image barrier with agricultural education that the program is for production agricultural only. Along with the image problem, programs are faced with more stringent graduation requirements limiting space in students' schedules for agricultural education. There is a perception that being enrolled in vocational programming including agricultural education you will be unable to move on to the next step of obtaining a college degree, because there is a stigma associated with vocational education that it is for students with little ability or nonacademic oriented students. These stigmas do not begin in high school. They are developed prior to ninth grade and can begin to influence students' choices before they ever exit the middle/junior high environment to embark on their high school career (Hoover, 1991). Students who do enroll in agricultural education point once again to the fact that it was the influence of counselors and their parents who helped them most in their decision to enroll in agricultural education. Many of these students have a positive attitude toward the content of the program, and that the program can have a significant impact on both farm and nonfarm students, male and female alike (Hoover, 1991). Guidance counselors should identify students who are interested in studying agriculturally related subjects and offer counseling and career information services about agriculturally related careers (Sutphin, 1995).

According to Dyer \& Osborne (1999) Illinois guidance counselors consider agriculture to be important in four different areas; economically, environmentally, 
technologically, and scientifically. This study also showed that the students who enrolled in agriculture were adequately prepared for college and graduation requirements. They also pointed out, as did Thompson (1993), that counselor support of agricultural programs will increase student's academic ability (Dyer \& Osborne, 1999).

Finding strategies that recruits students is often a local programs decision to determine what works for that instructor, school district, and that program and its supporters. Myers, Dyer and Brega in a 2003 study focused only on what the top rated agricultural programs noted as their most crucial recruiting strategies. The study listed seven strategies that these successful programs used to encourage students to enroll in agricultural education. The sixth most important strategy was to involve parent, teachers and support groups. Listed as important individuals to include as part of a programs support groups were guidance counselors from elementary, middle school and high school levels (Myers, Dyer, \& Breja, 2003).

The No Child Left Behind legislation contributed to issues in recruitment and problems attracting students to agricultural education. No Child Left Behind legislation included provisions for increased testing, and lack of core accreditation requirements for agricultural programs, and the negative impact of agricultural teachers not fitting the highly qualified teacher provisions of the law. There were concerns for funding of agricultural programs because of funding restrictions related to No Child Left Behind. These problems were addressed in many states by making agricultural classes equal to or offered as academic credit (Martin, Fritzsche, \& Ball, 2006).

To increase the quality of technical education in the United States and continue to help the economy Carl Perkins funding which was initially authorized by the federal 
government in 1984, was renewed in 2006 as Public Law 109-270. The provisions of the renewed version included: changing the terminology from vocational education to career and technical education, maintaining the state funding at five percent (5\%) of the states allocation and required that programs of study link academic and technical content and strengthen local accountability provisions that ensure program improvements. The Perkins Act provided 1.3 billion in career and technical education programs in all 50 states (Carl D. Perkins Career and Technical Education Improvement Act of 2006, 2006). Schools can use the funding to purchase equipment, staff development, career counseling and guidance activities and efforts for academic and vocational integration, hiring of staff and supplemental services for special populations (Johnson, 2002). To qualify for Perkins funding a school system must show that their students are completers in a program of study. Completers in West Virginia agriculture education programs must complete Agriculture 1, Supervised Agriculture Experience and two other content specific courses. After students complete the program of study, the Perkins funding formula is applied to reallocation of funds for the following year.

Unique to West Virginia, is the EDGE credits program that allows a high school student enrolled in a participating high school technical education program the ability to earn college credit while still in high school career and technical education classes. As of 2009 there were 53 public school systems and 10 community colleges participating in the EDGE program in West Virginia. With EDGE credits a high school student can earn an associate's degree with their high school diploma or save over $\$ 3,000$ in tuition towards a college degree (West Virginia Department of Education, n.d. d). 


\section{CHAPTER 3}

\section{Methodology}

\section{Purpose of the Study}

The purpose of this study was to determine the methods that guidance or vocational counselors in West Virginia public schools use to schedule students into agricultural education programs in their school. This study will help teachers understand how guidance counselors schedule students and help diffuse the perceptions that counselors do not value agricultural education program. By understanding what factors impact student placement in career and technical education programs by guidance counselors and how to better create channels of communications between the counselors and the teachers.

\section{Research Questions}

The following research questions will guide the study:

1. What criteria determines student placement in career and technical education programs?

2. How do you determine which students will be placed in each career and technical education program?

3. Are Individualized Education Plans for Special Needs students reviewed by counselors to determine which career and technical education program would best suit the student?

4. What characteristics make career and technical education popular choices with students in West Virginia? 
5. Does completer's certification or EDGE credits make a difference in scheduling students?

6. How much does a guidance counselor understand about career and technical education funding and guidelines?

\section{Research Design}

A descriptive research design using a mailed questionnaire was used for this study to determine methods used by West Virginia high school guidance counselors to determine placement in career and technical education programs, specifically agricultural education classes. A questionnaire was designed to determine what criteria guidance counselors use in student placement and the counselors understanding of career and technical education. According to Ary, Jacobs, Razavieh, Sorensen (2006), surveys allow the researcher to measure the attitudes and opinions of the respondents to collect information from a sample of the target. Surveys also allow the population to be reached regardless of location. The information can be gathered in a shorter period of time and results can be guaranteed as confidential and anonymous, giving respondents a chance to answer more honestly on the instrument. Another advantage of a mailed questionnaire is that it does not allow for interviewer bias. The disadvantage to this method is misinterpretations of the questions by respondents and low return rate. Return rate can be affected by the length of the questionnaire, the cover letter that accompanies it, and the interest that it arouses in the participants (Ary, Jacobs, Razavieh, \& Sorensen, 2006).

Survey research has five errors that need to be controlled. To avoid frame error the list of guidance counselors was requested from the West Virginia Department of Education, A second list was created by emailing and asking each West Virginia 
agriculture teacher to submit their counselors name and school address. The two sources were necessary as the state department data did not reflect staff changes, during the current school year, and we were only interested in schools with current agricultural education programs. Selection errors were avoided by reviewing the combined list for duplications. To avoid non-response error, comparisons were made between early and late respondents to find the differences using the Pearson Chi-Square. The Pearson ChiSquare showed no significant differences between the variables, therefore generalization for guidance counselors perceptions could be made for the total population.

\section{Population}

The population used in this study was all guidance counselors at schools in West Virginia who currently have an agricultural education program. A census of the entire population of guidance counselors in the state that currently have an agricultural education program was conducted, eliminated sampling error. It is known that there are agriculture programs in 46 of the 55 counties. All agricultural education teachers in the state were asked to send their schools guidance counselor's names and current mailing addresses. A second list provided by the State Department of Education and individual school websites were used to compile a complete and accurate list of all guidance counselors in the schools with agricultural education programs.

\section{Instrumentation}

The instrument was revised from one used in a previous study by McGee \& Bender (1975). The revised instrument was presented to a panel of experts which consisted of teacher educators in Agricultural and Extension Education at West Virginia University. Each expert included on the panel had extensive teaching and/or extension 
field experience. The panel of experts concluded the instrument had content and face validity.

The reliability of the instrument was determined using the final data set from all respondents. Because the data consisted of nominal and ordinal scale responses, Spearman-Brown split half statistic was used to establish the instruments reliability. Reliability was found to be exemplary with a coefficient of 0.87 (Robinson, Shaver, \& Wrightsman, 1991). The instrument was determined to be reliable. Part one of the questionnaire consisted of 39 Likert scale questions on guidance counselors perceptions of various aspects of agricultural programming and scheduling of students into those programs. The counselors were asked to answer using five possible choices of Strongly Agree, Agree, Disagree, Strongly Disagree or Not Applicable. Part two consisted of three questions where the counselors were asked to rank their feelings on various aspects of student scheduling and current agricultural program merits. The third section asked demographics questions including: gender, age, length of employment, ethnic background, number of students with IEP's, size of school, past experience of the counselor with youth agriculture programs either in high school or through 4-H and current programs offered at their school.

\section{Data Collection Procedures}

A packet which included a cover letter, copy of the instrument, and a selfaddressed stamped envelope was mailed to all guidance counselors in West Virginia high schools with an affiliate agricultural program. The cover letter stated a firm deadline for return. Seven days after the first deadline, a second packet was sent to all nonrespondents. Follow-up email reminders were sent to non-respondents. The researchers 
compared early respondents to late respondents, no differences were found. This allows the researchers draw inferences to the population because late respondents are similar to non-respondents (Dillman, 2000)

\section{Analysis of Data}

The data were entered into an Excel spreadsheet. The data were then transferred to SPSS for analysis, and the significance level was set a priori at $\leq .05$ for all statistical tests. Descriptive analyses were performed on the data and the appropriate methods of reporting each type of data were used. Chi square test of independence was used to compare the late respondents with the early respondents to determine if the two variables are independent of one another. For valid interpretation of data to be made using the Chi Square, the observations must be independent, randomly selected and in mutually exclusive categories. The measurements were reported as frequencies.

\section{Use of Findings}

Agricultural educators will use findings from this study to improve communication with guidance counselors and develop ideas for promoting agricultural education courses to their students. This study will also serve as a starting point for developing continuing education for guidance counselors and agricultural educators. 


\section{CHAPTER 4}

\section{Findings}

\section{Purpose of the Study}

The purpose of this study was to determine the methods that guidance or vocational counselors in West Virginia public schools use to schedule students into agricultural education programs in their school. This study will help teachers understand how guidance counselors schedule students and help diffuse the perceptions that counselors do not value agricultural education program. By understanding what factors impact student placement in career and technical education programs by guidance counselors and how to better create channels of communications between the counselors and the teachers.

\section{Research Questions}

The following research questions guided this study:

1. What criteria determines student placement in career and technical education programs?

2. How do you determine which students will be placed in each career and technical education program?

3. Are Individualized Education Plans for Special Needs students reviewed by counselors to determine which career and technical education program would best suit the student?

4. What characteristics make career and technical education popular choices with students in West Virginia? 
5. Does completer's certification or EDGE credits make a difference in scheduling students?

6. How much does a guidance counselor understand about career and technical education funding and guidelines?

\section{Demographics}

A majority $(n=72,76.6 \%)$ of the respondents were female. Twenty- two $(23.4 \%)$ of the respondents were male (see Table 1).

Table 1

Gender of Participants

\begin{tabular}{lcc}
\hline & $\mathrm{N}$ & $\%$ \\
\hline Male & 22 & 23.4 \\
Female & 72 & 76.6 \\
\hline
\end{tabular}

The respondents were asked to use five year incremental categories to report their years of experience as a guidance counselor. Thirty-one $(33.3 \%)$ indicated that they had been counselors for 0 - 5 years, $25(26.9 \%)$ indicated they had been counselors over 20 years. Twenty-four $(25.8 \%)$ were counselors for $6-10$ years, seven $(7.5 \%)$ were counselors for 11-15 years, while six $(6.5 \%)$ had been counselors for $16-20$ years (see Table 2). 
Table 2

Years as a Guidance Counselor

\begin{tabular}{lcc}
\hline & $\mathrm{N}$ & $\%$ \\
\hline $0-5$ years & 31 & 33.3 \\
$6-10$ years & 24 & 25.8 \\
$11-15$ years & 7 & 7.5 \\
$16-20$ years & 6 & 6.5 \\
over 20 years & 25 & 26.9 \\
\hline
\end{tabular}

Respondents were asked their ethnicity and were asked to choose one of the following five categories, American Indian or Alaskan Native, Asian or Pacific Islander, Black, Hispanic and White. Ninety $(97.8 \%)$ of the counselors indicated that they were white. Two $(2.2 \%)$ were Hispanic. No participants indicated that they were American Indian or Alaskan Native, Asian or Pacific Islander, or Black (see Table 3).

Table 3

Ethnicity of Guidance Counselors

\begin{tabular}{lcc}
\hline & $\mathrm{N}$ & $\%$ \\
\hline American Indian or Alaskan Native & 0 & .0 \\
Asian or Pacific Islander & 0 & .0 \\
Black & 0 & .0 \\
Hispanic & 2 & 2.2 \\
White & 90 & 97.8 \\
\hline
\end{tabular}


Respondents were asked to indicate their current residential setting. Fifty-three (56.4\%) indicated that they lived in a rural area, not on a farm. Sixteen (17\%) lived in a suburb, $13(13.8 \%)$ resided in a city, while $12(12.8 \%)$ lived on a farm or ranch (see Table 4).

Table 4

Residence of Guidance Counselors

\begin{tabular}{lll}
\hline & $\mathrm{N}$ & $\%$ \\
\hline On a farm or ranch & 12 & 12.8 \\
In a city & 13 & 13.8 \\
In a suburb & 16 & 17.0 \\
In a rural area not on a farm & 53 & 56.4 \\
\hline
\end{tabular}

Counselors were asked to indicate their age. The age categories were less than $25,24-35,35-45$, and $45-55$ and over 55 years. Twenty-nine (31.5\%) counselors indicated that they were over 55 years of age, 26 (28.3\%) respondents were $45-55$ years of age, $19(20.7 \%)$ were $24-35$ years of age, while $18(19.6 \%)$ were $35-45$ years of age (see Table 5). 
Table 5

Age of Guidance Counselors

\begin{tabular}{lcc}
\hline & $\mathrm{N}$ & $\%$ \\
\hline less than 25 years & 0 & .0 \\
$24-35$ years & 19 & 20.7 \\
$35-45$ years & 18 & 19.6 \\
$45-55$ years & 26 & 28.3 \\
over 55 years & 29 & 31.5 \\
\hline
\end{tabular}

Counselors were asked if they had been enrolled in agricultural education programs during their high school careers. They were given the choices of yes, no and not offered in my school. Seventy-five (81.5\%) indicated that they had not been enrolled in agricultural education courses in high school, while six (6.5\%) indicated that they had been enrolled in agricultural education in high school. Eleven (12\%) responded that agricultural education was not offered in their high school (see Table 6).

Table 6

Guidance Counselors Enrolled in Agricultural Education during High School

\begin{tabular}{lcc}
\hline & N & $\%$ \\
\hline No & 75 & 81.5 \\
Yes & 6 & 6.5 \\
Not offered in my high school & 11 & 12.0 \\
\hline
\end{tabular}


The counselors were asked if they had been a 4-H member as a youth. Fifty $(53.8 \%)$ indicated that they were not in $4-\mathrm{H}$, while $43(46.2 \%)$ said that they had been $4-$ H members as youth (see Table 7).

Table 7

Guidance Counselors Who Were Members of 4-H as a Youth

\begin{tabular}{lcc}
\hline & $\mathrm{N}$ & $\%$ \\
\hline No & 50 & 53.8 \\
Yes & 43 & 46.2 \\
\hline
\end{tabular}

Counselors were asked how many Individualized Education Plans (IEP) were being implemented in their high school. Counselors were asked to use the choices of less than $100,100-250,250-500$, or more than 500 . Forty-one $(48.2 \%)$ of the respondents indicated that there were less than 100 students on a IEP plan in their high school. Thirty-seven (43.5\%) said that there were between 100 - 250 students on Individualized Education Plans, while $5(5.9 \%)$ responded that there were 250 to 500 plans being used in their school, while two (2.4\%) indicated that there were more than 500 individualized education plans in their schools (see Table 8). 
Table 8

Number of Individualized Education Plans per School

\begin{tabular}{lcc}
\hline & $\mathrm{N}$ & $\%$ \\
\hline Less than 100 & 41 & 48.2 \\
$100-250$ & 37 & 43.5 \\
$250-500$ & 5 & 5.9 \\
$>500$ & 2 & 2.4 \\
\hline
\end{tabular}

Counselors were asked to indicate the size of their high school based on the guidelines used by the West Virginia Secondary School Athletic Commission. They were given the categories of A, AA, AAA, and AAAA. Forty-five $(50.6 \%)$ of the counselors indicated that their school was AAA (619 students or more). Twenty-four (27\%) were from AA (340 to 618 students) high schools. Fourteen (15.7\%) indicated that they were from A (less than 340 students) high schools. There were six $(6.7 \%)$ respondents who were from AAAA (even though there are no longer any high schools in West Virginia listed as AAAA) high schools (see Table 9).

Table 9

Size of School Based on West Virginia Secondary School Athletic Commission Guidelines

\begin{tabular}{lcc}
\hline & $\mathrm{N}$ & $\%$ \\
\hline A & 14 & 15.7 \\
AA & 24 & 27.0 \\
AAA & 45 & 50.6 \\
AAAA & 6 & 6.7 \\
\hline
\end{tabular}


When counselors were asked about which areas of concentration were offered in the agriculture programs in their school, seven counselors indicated they did not know which concentrations were offered in their schools. Counselors in the study indicated areas of concentration in theirs schools to include: food products and processing $(\mathrm{N}=$ 22), plant systems $(\mathrm{N}=60)$, animal systems $(\mathrm{N}=70)$, and 44 responded their school offered a concentration in power, structural and technical systems. Natural resource systems concentration was reported by 44 respondents, 20 reported environmental service systems, while, 56 respondents reported offering agribusiness systems areas of concentration (see Table 10).

Table 10

Agriculture Education Concentrations Offered

\begin{tabular}{|c|c|c|c|c|}
\hline & \multicolumn{2}{|c|}{ No } & \multicolumn{2}{|c|}{ Yes } \\
\hline & $\mathrm{N}$ & $\%$ & $\mathrm{~N}$ & $\%$ \\
\hline Food Products and Processing & 68 & 75.6 & 22 & 24.4 \\
\hline Plant systems & 30 & 33.3 & 60 & 66.7 \\
\hline Animal systems & 20 & 22.2 & 70 & 77.8 \\
\hline $\begin{array}{l}\text { Power structural and technical } \\
\text { systems }\end{array}$ & 46 & 51.1 & 44 & 48.9 \\
\hline Natural resource systems & 30 & 33.3 & 60 & 66.7 \\
\hline Environmental service systems & 70 & 77.8 & 20 & 22.2 \\
\hline Agribusiness systems & 34 & 37.8 & 56 & 62.2 \\
\hline Do not know & 84 & 92.3 & 7 & 7.7 \\
\hline
\end{tabular}


Each counselor was asked to identify how many agriculture teachers were in their school. Their responses were given in a number of teachers in their school. Sixty-three $(70 \%)$ of the counselors responded that their school has only one agriculture teacher.

Eleven $(12.2 \%)$ counselors responded that their school had 2 teachers in their programs. Eight $(8.9 \%)$ indicated that their school had three teachers in the program. Three $(3.3 \%)$ indicated that they had four teachers at their schools program. Two $(2.2 \%)$ indicated that there was no agriculture program at their school. There were 1.3, 1.5 and 2.5 teachers per school reported by one (1.1\%) counselor each respectively (see Table 11).

Table 11

Number of Agriculture Teachers in Each School

\begin{tabular}{lcc}
\hline & $\mathrm{N}$ & $\%$ \\
\hline .0 & 2 & 2.2 \\
1.0 & 63 & 70.0 \\
1.3 & 1 & 1.1 \\
1.5 & 1 & 1.1 \\
2.0 & 11 & 12.2 \\
2.5 & 1 & 1.1 \\
3.0 & 8 & 8.9 \\
4.0 & 3 & 3.3 \\
\hline
\end{tabular}

When asked to rank their most important reason for scheduling students in agricultural education programs, a majority of the respondents, $81(95.3 \%)$ ranked student interest in the subject as the number one reason to schedule students into 
agricultural education programs. Three respondents (3.5\%) ranked student interest second, one (1.2\%) ranked it third and none of the respondents ranked it fourth or fifth (see Table 12).

Forty respondents (48.2\%) ranked that students could be completers in an area as the second most important reason to schedule students into agricultural education programs. One respondent (1.2\%) ranked students can become completers in an area as the number one reason, while $31(37.3 \%)$ ranked it third, six (7.2\%) ranked it fourth and five $(6.0 \%)$ ranked it fifth as a reason to schedule students into agricultural education programs (see Table 12).

Two respondents (2.4\%) marked that the first reason to schedule students into agricultural education classes was because they could earn EDGE credit. Twenty-three respondents (24.5\%) ranked it second, 53 (56.4\%) said that their third reason for scheduling students was for their ability to gain EDGE credits by being enrolled in these classes. Eleven (11.7\%) indicated that was their fourth criteria for enrolling student in agriculture courses and five (5.3\%) of respondents ranked so that they had a chance to gain EDGE credits as fifth among the reasons why they enrolled students in agricultural education (see Table 12.)

One respondent (1.2\%) said that their first reason for scheduling students in to agriculture classes is the students' positive image of the instructor. Twelve (14.3\%) noted that their second and third reason for scheduling students into agricultural education is the students perceptions of the instructor. Forty-nine (58.3\%) said that the students image of the instructor was their fourth reason for scheduling them into 
agricultural education programs. Ten (11.9\%) responded that this was their fifth scheduling students into agricultural education classes (see Table 12).

No respondents said that they placed students into an agricultural class because it fits into their schedule. Three (3.6\%) noted it was a second reason, $5(6 \%)$ responded that their third reason to schedule students into agricultural classes was that it fit into their schedules. Twelve respondents (14.3\%) responded this was their fourth option while 64 respondents $(76.2 \%)$ said that this was their fifth consideration for enrolling students into agricultural education was because it fit in the student's schedule (see Table 12.)

Table 12

Counselors Ranking of the Most Important Reasons to Schedule Students in Agricultural Education Programs

\begin{tabular}{|c|c|c|c|c|c|c|c|c|c|c|}
\hline & \multicolumn{2}{|c|}{ First } & \multicolumn{2}{|c|}{ Second } & \multicolumn{2}{|c|}{ Third } & \multicolumn{2}{|c|}{ Fourth } & \multicolumn{2}{|c|}{ Fifth } \\
\hline & $\mathrm{N}$ & $\%$ & $\mathrm{~N}$ & $\%$ & $\mathrm{~N}$ & $\%$ & $\mathrm{~N}$ & $\%$ & $\mathrm{~N}$ & $\%$ \\
\hline Student interest in subject & 81 & 95.3 & 3 & 3.5 & 1 & 1.2 & 0 & .0 & 0 & .0 \\
\hline $\begin{array}{l}\text { Students can be } \\
\text { completers in the area }\end{array}$ & 1 & 1.2 & 40 & 48.2 & 31 & 37.3 & 6 & 7.2 & 5 & 6.0 \\
\hline $\begin{array}{l}\text { Students can earn EDGE } \\
\text { credits }\end{array}$ & 2 & 2.4 & 25 & 29.8 & 35 & 41.7 & 17 & 20.2 & 5 & 6.0 \\
\hline $\begin{array}{l}\text { Students have positive } \\
\text { image of instructor }\end{array}$ & 1 & 1.2 & 12 & 14.3 & 12 & 14.3 & 49 & 58.3 & 10 & 11.9 \\
\hline $\begin{array}{l}\text { Fits in the students } \\
\text { schedule }\end{array}$ & 0 & .0 & 3 & 3.6 & 5 & 6.0 & 12 & 14.3 & 64 & 76.2 \\
\hline
\end{tabular}

When asked to rank the factors that they felt helped students with disabilities succeed in high school, a majority of the respondents, 43 (55\%) ranked "IEP's which 
properly reflect their classroom needs and present level of educational performance" as the number one reason students with Individualized Education Plans are successful in their academic endeavors. Thirteen respondents (16.7\%) ranked the reflecting needs and present levels as second, $12(15.4 \%)$ ranked it third, seven (9\%) ranked it fourth, and three (3.8\%) ranked it fifth (see Table 13).

Twenty - two respondents (28.6\%) ranked that "students were in classes with teachers that kept them interested" as their first choice as to why students with IEP's are successful. Seventeen (22.1\%) ranked it second, nineteen (24.7\%) ranked it third, 13 (16.9\%) ranked it fourth and six (7.8\%) ranked students in classes with teachers that kept them interested as fifth (see Table 13).

Two respondents (2.6\%) ranked "Parents are actively involved in their education" as the first response to why students with IEP's have academic success. Three respondents (3.9\%) ranked it second, $12(15.6 \%)$ ranked it third, $15(19.5 \%)$ ranked it fourth, and 45 (58.4\%) ranked it fifth as to why students with Individualized education plans has academic success (see Table 13).

Six respondents (7.8\%) ranked first that “students with IEP's have outlets or special services to help them succeed unlike their regular education peers". Twenty (26\%) ranked this second, $16(20.8 \%)$ ranked it third , $24(31.2 \%)$ ranked it fourth and 11 (14.3\% ranked it fifth as the reason that students with IEP's have outlets or special education services which to help them succeed until like their regular education peers (see Table 13). 
Table 13

Counselors Ranking of Perceptions of Students with Individualized Education Plans

Services for Academic Success.

\begin{tabular}{|c|c|c|c|c|c|c|c|c|c|c|}
\hline & \multicolumn{2}{|c|}{ First } & \multicolumn{2}{|c|}{ Second } & \multicolumn{2}{|c|}{ Third } & \multicolumn{2}{|c|}{ Fourth } & \multicolumn{2}{|c|}{ Fifth } \\
\hline & $\mathrm{N}$ & $\%$ & $\mathrm{~N}$ & $\%$ & $\mathrm{~N}$ & $\%$ & $\mathrm{~N}$ & $\%$ & $\mathrm{~N}$ & $\%$ \\
\hline $\begin{array}{l}\text { IEP's are reflecting needs } \\
\text { and present levels }\end{array}$ & 43 & 55.1 & 13 & 16.7 & 12 & 15.4 & 7 & 9.0 & 3 & 3.8 \\
\hline $\begin{array}{l}\text { In classes with teachers } \\
\text { that keep them interested }\end{array}$ & 22 & 28.6 & 17 & 22.1 & 19 & 24.7 & 13 & 16.9 & 6 & 7.8 \\
\hline $\begin{array}{l}\text { Parents are actively } \\
\text { involved in their } \\
\text { education }\end{array}$ & 2 & 2.6 & 3 & 3.9 & 12 & 15.6 & 15 & 19.5 & 45 & 58.4 \\
\hline $\begin{array}{l}\text { They have outlets to help } \\
\text { succeed unlike regular } \\
\text { education students }\end{array}$ & 6 & 7.8 & 20 & 26.0 & 16 & 20.8 & 24 & 31.2 & 11 & 14.3 \\
\hline $\begin{array}{l}\text { They are filtered into } \\
\text { classed with teacher who } \\
\text { works well with special } \\
\text { education students }\end{array}$ & 6 & 7.8 & 25 & 32.5 & 18 & 23.4 & 17 & 22.1 & 11 & 14.3 \\
\hline
\end{tabular}

Six respondents $(7.8 \%)$ ranked students with IEP's are filtered into classes with teachers who are known to work well with special education students first. Twenty-five $(32.5 \%)$ ranked it second, $18(23.4 \%)$ ranked it third, $17(22.1 \%)$ ranked it fourth and $11(14.3 \%)$ ranked students with IEPS are filtered into classes with teacher who are known to work well with them as fifth (see Table 13.)

When guidance counselors were asked to rank their perceptions of importance for scheduling students into agricultural education programs, 67 (82.7\%) ranked agricultural education teachers concern for student agricultural achievement and personal growth as number one. Ten (12.3\%) ranked it second, and three $(3.7 \%)$ ranked it third, while one 
(1.2\%) ranked it fourth while no respondents ranked student agricultural achievement and personal growth fifth or sixth in their rankings (see Table 14).

Two (2.5\%) respondents ranked agricultural education teachers concern for chapter success as number the number one reason to enroll students in agricultural education programs. Seven (8.8\%) respondents ranked chapter success second, 18 (22.5\%) ranked it third, 20 (25\%) ranked chapter success fourth. Thirty-two (40\%) of respondents ranked chapter success fifth, and one (1.3\%) ranked chapter success sixth (see Table 14.).

Thirteen (15.9\%) of the respondents ranked that agricultural education teachers concerned with students learning and mastering CSO's to pass required testing as number one reason to schedules students and agricultural education programs. Twenty-six (31.7\%) respondents ranked it second, 14 (17.1\%) ranked it third, 12 (14.6\%) ranked student's learning and mastering CSO's to pass required testing as fourth. Seventeen (20.7\%) respondents ranked it fifth while, none of the respondents ranked students learning and mastering CSO's to pass required testing as being what agricultural educators are most concerned with (see Table 14).

None of the counselors ranked that agricultural education's concern for chapter involvement in school and community as a number one importance for scheduling students into agricultural education programs, eight (10\%) ranked it second, 22 (27.5\%) ranked it third. Thirty-six respondents (45\%) ranked fourth, 14 (17.5\%) ranked it fifth and none of the respondents ranked agricultural education teachers concern with chapter involvement in school and community sixth as a reason for students to be enrolled in an agricultural education classes (Table 14). 
Table 14

Guidance Counselors Perceptions of Students Enrolled in Agricultural Education.

\begin{tabular}{|c|c|c|c|c|c|c|c|c|c|c|c|c|}
\hline & \multicolumn{2}{|c|}{ First } & \multicolumn{2}{|c|}{ Second } & \multicolumn{2}{|c|}{ Third } & \multicolumn{2}{|c|}{ Fourth } & \multicolumn{2}{|c|}{ Fifth } & \multicolumn{2}{|c|}{ Sixth } \\
\hline & $\mathrm{N}$ & $\%$ & $\mathrm{~N}$ & $\%$ & $\mathrm{~N}$ & $\%$ & $\mathrm{~N}$ & $\%$ & $\mathrm{~N}$ & $\%$ & $\mathrm{~N}$ & $\%$ \\
\hline $\begin{array}{l}\text { Student achievement and } \\
\text { personal growth }\end{array}$ & 67 & 82.7 & 10 & 12.3 & 3 & 3.7 & 1 & 1.2 & 0 & .0 & 0 & .0 \\
\hline Chapter success & 2 & 2.5 & 7 & 8.8 & 18 & 22.5 & 20 & 25.0 & 32 & 40.0 & 1 & 1.3 \\
\hline $\begin{array}{l}\text { Student learning and } \\
\text { mastering CSO's to } \\
\text { master tests }\end{array}$ & 13 & 15.9 & 26 & 31.7 & 14 & 17.1 & 12 & 14.6 & 17 & 20.7 & 0 & .0 \\
\hline $\begin{array}{l}\text { Chapter involvement in } \\
\text { school and community }\end{array}$ & 0 & .0 & 8 & 10.0 & 22 & 27.5 & 36 & 45.0 & 14 & 17.5 & 0 & .0 \\
\hline $\begin{array}{l}\text { Student involvement in } \\
\text { school and community }\end{array}$ & 0 & .0 & 30 & 37.5 & 23 & 28.7 & 11 & 13.8 & 16 & 20.0 & 0 & .0 \\
\hline Other & 1 & 25.0 & 2 & 50.0 & 0 & .0 & 0 & .0 & 0 & .0 & 1 & 25.0 \\
\hline
\end{tabular}

Respondents were asked to rank the importance of scheduling students into agricultural education programs based on agricultural education teachers concern with student involvement in school and community no respondents ranked this number one, 30 (37.5\%) ranked it second highest importance, 23 (28.7\%) ranked it third. Eleven counselors $(13.8 \%)$ choose the agricultural education teacher being concerned with student involvement in the school and community fourth, $16(20 \%)$ ranked it fifth and none of the respondents placed it sixth The "other" option as a reason to enroll students in agricultural education programs was rank first by one respondent and sixth by one respondent and two respondents ranked "other" reasons to enroll students in agricultural education second No respondents ranked "other" third, fourth and fifth (see Table 14). 


\section{Guidance Counselors Perceptions of Agricultural Teachers}

Guidance counselors were asked their perceptions of the agriculture teacher(s) and their perceptions of the agriculture education program. Seventy-nine $(83.2 \%)$ of respondents strongly agreed that agriculture teachers are firm believers in the worth and value of their program, $16(16.8 \%)$ agreed and none disagreed, strongly disagreed or felt this was not applicable (see Table 15).

When asked to indicate their level of agreement with the statement "agricultural education teachers seek to maintain and increase the enthusiasm of their students for their studies," 52 respondents $(54.7 \%)$ noted that they strongly agreed with the statement, 41 $(43.2 \%)$ agreed, while one (1.1\%) disagreed and one (1.1\%) said that it was not applicable. No one strongly disagreed with the statement that agricultural teachers increase the enthusiasm of their students toward their studies (See Table 15)..

Guidance counselors were asked to indicate their level of agreement with statement "agricultural education teachers are not able to communicate effectively with individuals not directly related to agriculture.” No respondents strongly agree or found not applicable. One respondent (1.1\%) agreed that agriculture teachers do not communicate well with people not related to agriculture, while 65 respondents $(69.1 \%)$ strongly disagreed with the statement and $28(29.8 \%)$ responded that they disagreed with the statement that agriculture teachers did not communicate effectively with individuals not directly related to agriculture (see Table 15)..

When asked if guidance counselors felt that "agricultural teachers tend to be less cooperative then other teachers in the school," 62 (65.3\%) strongly disagreed and 30 
(32.6\%) disagreed. While two (2.1\%) respondents agreed and no respondents strongly agreed or indicated that the statement was not applicable (see Table 15).

When asked if "agricultural teachers seem to go out of their way to help other teachers in the school," 50 respondents (54.3\%) agreed that they do help others, 22 (23.9\%) strongly agreed, while $14(15.2 \%)$ disagreed, one (1.1\%) strongly disagreed, and five (5.4\%) responded that it was not applicable (see Table 15

Guidance counselors were asked to respond to the statement "agricultural teachers seem to be involved and interested in the development of the total student," 44 (46.3\%) strongly agreed and $43(45.3 \%)$ agreed that agriculture teachers are interested in the development of the total student. Six respondents (6.63\%) disagreed and two (2.1\%) responded not applicable while, none of the respondents strongly disagreed that agriculture teachers are interested in the development of the total student (see Table 15).

When asked to indicate their level of agreement with the statement "It is an agricultural education teacher's job to assist with career/guidance counseling for students in an agricultural related area," $18(19.1 \%)$ of the respondents strongly agreed with the statement. Sixty-six (70.2\%) agreed, seven (7.4\%) disagreed, two (2.0\%) strongly disagreed and one (1.1\%) felt it was not applicable that agriculture teachers assist with career/guidance counseling for students in an agricultural areas (see Table 15).

Counselors were asked to indicate their level of agreement with the statement, "agricultural teachers have success with students with disabilities." Sixty-five (69.9\%) agreed with the statement, $22(23.7 \%)$ strongly agreed, while two $(2.2 \%)$, strongly disagreed, and four (4.3\%) responded not applicable that agricultural teachers have success with students with disabilities (see Table 15). 
Counselors when asked to indicate the level agreement with the statement "agricultural education teachers have higher expectations for their students than nonagricultural education teachers do," 67 (73.6\%) disagreed with statement. Three $(3.3 \%)$ strongly agreed, eight (8.8\%) agreed, six (6.6\%) strongly disagreed and seven $(7.7 \%)$ responded not applicable that agriculture teachers have higher expectations for their students than other teachers do (see Table 15).

Table 15

Guidance Counselors Perceptions of Agriculture Teachers

\begin{tabular}{ccccccccc}
$\begin{array}{c}\text { Strongly } \\
\text { Agree }\end{array}$ & Agree & Disagree & $\begin{array}{c}\text { Strongly } \\
\text { Disagree }\end{array}$ & $\begin{array}{c}\text { Not } \\
\text { Applicable }\end{array}$ \\
\hline N $\quad \%$ & N & $\%$ & N & $\%$ & N & $\%$ & N & $\%$
\end{tabular}

Firm believers in the worth and value of their programs

$\begin{array}{llllllllll}79 & 83.2 & 16 & 16.8 & 0 & .0 & 0 & .0 & 0 & .0\end{array}$

Seek to maintain and increase the enthusiasm of their students for their studies 52 54.741 43.21 1.1 $.0 \quad 1$ 1.1

Not able to communicate effectively with individuals not directly related to agriculture

$\begin{array}{llllllllll}0 & 0.0 & 1 & 1.1 & 28 & 29.8 & 65 & 69.1 & 0.0 & 0.0\end{array}$


Table 15 (continued)

Guidance Counselors Perceptions of Agriculture Teachers

\begin{tabular}{|c|c|c|c|c|c|c|c|c|}
\hline $\begin{array}{c}\text { Strongly } \\
\text { Agree }\end{array}$ & & & & ree & & & & cable \\
\hline $\mathrm{N} \quad \%$ & $\mathrm{~N}$ & $\%$ & $\mathrm{~N}$ & $\%$ & $\mathrm{~N}$ & $\%$ & $\mathrm{~N}$ & $\%$ \\
\hline
\end{tabular}

Tend to be less

cooperative than other

teachers in the school

$\begin{array}{llllllllll}0 & 0.0 & 2 & 2.1 & 31 & 32.6 & 62 & 65.3 & 0.0 & 0.0\end{array}$

Seem to go out of their

way to help other teachers

in the school

$\begin{array}{llllllllll}22 & 23.9 & 50 & 54.3 & 14 & 15.2 & 1 & 1.1 & 5 & 5.4\end{array}$

involved and interested in

the development of the

total student

$\begin{array}{llllllllll}44 & 46.3 & 43 & 45.3 & 6 & 6.3 & 0 & .0 & 2 & 2.1\end{array}$

teachers job is to assist

with career guidance

counseling for students in

an agricultural related

area

$\begin{array}{llllllllll}18 & 19.1 & 66 & 70.2 & 7 & 7.4 & 2 & 2.1 & 1 & 1.1\end{array}$

have success with

$\begin{array}{lllllllllll}\text { students with disabilities } & 22 & 23.7 & 65 & 69.9 & 2 & 2.2 & 0 & .0 & 4 & 4.3\end{array}$

Agricultural education

teachers have higher

expectations for their

students than teachers

$\begin{array}{lll}3 & 3.3 \quad 8\end{array}$

$\begin{array}{llll}8.8 & 67 & 73.6 & 6\end{array}$

$\begin{array}{lll}6.6 & 7 & 7.7\end{array}$

Our schools has all the

needed equipment to

conduct a quality program

a variety of teaching

techniques

$\begin{array}{llllllllll}31 & 33.7 & 56 & 60.9 & 3 & 3.3 & 0 & .0 & 2 & 2.2\end{array}$

Respondents were asked to indicate their agreement with the statement, "Our schools agricultural education teacher has all the needed equipment to conduct a quality 
program." Thirty-eight (44.7\%) agreed that they did have all the equipment needed for a quality program, seven (8.2\%) strongly agreed, 29 (34.1\%) disagreed, five (5.9\%) strongly disagreed and six (7.1\%) felt that the schools equipment needs were not applicable to a quality program (see Table 15).

Counselors were asked if they thought "agricultural education teachers use a variety of teaching techniques," $56(60.9 \%)$ responded that they agreed and $31(33.7 \%)$ strongly agreed, three (3.3\%) disagreed and two felt that this was not applicable and none responded that they strongly disagreed that agricultural teachers use a variety of teaching techniques (see Table 15).

\section{Guidance Counselor's Perceptions of how the Agriculture Education Programs \\ Enrollment Affects Students}

Guidance Counselors when asked to respond to the statement "In my opinion a graduate of a high school agricultural education program is generally only suited for unskilled work," 59 (62.8\%) of respondents strongly disagreed, 33 (35.1\%) disagreed with the statement. One respondent (1.1\%) strongly agreed and one (1.1\%) agreed and no respondents marked not applicable that high school graduates of an agricultural education program are generally only suited for unskilled work (see Table 16).

When asked their perception if "laboratory teaching and shop activities of agricultural education programs appeared to be well organized," $51(54.3 \%)$ of respondents agreed while 37 (39.4\%) strongly agreed that activities looked well organized. Five (5.3\%) disagreed; one (1.1\%) felt that this was not applicable while no respondents strongly disagreed that the laboratory and shop activities of agricultural education programs appear to be well organized (see Table 16). 
Counselors were also asked to indicate their level of agreement with the statement "agricultural education programs in high school should be intended mainly for youth with limited academic talent," 74 respondents (77.9\%) strongly disagreed and 21 (22.1\%) disagreed that agriculture education was intended for youth with limited academic talents. No respondents chose strongly agreed, agreed or not applicable (see Table 16).

When asked if their level of agreement with the statement "agricultural education classes develop leadership abilities needed in fulfilling occupational, social and civic responsibilities," $56(58.9 \%)$ responded that they strongly agreed, $36(37.9 \%)$ agreed that it does teach occupational, social and civic responsibilities. Two disagreed (2.1\%), one (1.1\%) strongly disagreed and none responded not applicable (see Table 16).

When asked if "course content offered in an agricultural education program could fulfill course requirements for some academic courses," 59(64.1\%) agreed, nine (9.8\%) strongly agreed. Fifteen respondents (16.3\%) disagreed and three (3.3\%) strongly disagreed, while six (6.5\%) believed that it was not applicable that course content from agricultural education could fulfill courses requirements for other academic courses (see Table 16).

When asked if "Agricultural education classes should be allowed to count for science credit needed for graduation," 44 (49.4\%) agreed, 25 (28.1\%) disagreed and 14 (15.7\%) strongly agreed that agriculture classes should count for science credit. Five (5.6\%) strongly disagreed with allowing agriculture classes to count as science credits and one (1.1\%) felt it was not applicable (see Table 16).

Counselors agreed that "agricultural education classes are a place for students to learn skills they can use in the future." Fifty-one (53.7\%) responded strongly agreed and 
$44(46.3 \%)$ agreed while respondents disagreed, strongly disagreed or felt that it was not applicable (see Table 16).

When asked if counselors perceived "agricultural education classes as a place for students to relax from the pressures of the regular class requirements but still learn new skills," 50 respondents (52.1\%) agreed with the statement. Thirty-one (32.2\%) respondents disagreed with the statement, while five (5.2\%) strongly agreed, eight ( $8.3 \%)$ strongly disagreed and two (2.1\%) felt that it was not applicable (see Table 16).

Table 16

Guidance Counselor's Perceptions of How the Agriculture Education Programs Enrollment Affects Students

\begin{tabular}{|c|c|c|c|c|c|c|c|c|c|c|}
\hline & \multicolumn{2}{|c|}{$\begin{array}{l}\text { Strongly } \\
\text { Agree }\end{array}$} & \multicolumn{2}{|c|}{ Agree } & \multicolumn{2}{|c|}{ Disagree } & \multicolumn{2}{|c|}{$\begin{array}{l}\text { Strongly } \\
\text { Disagree }\end{array}$} & \multicolumn{2}{|c|}{$\begin{array}{c}\text { Not } \\
\text { Applicable }\end{array}$} \\
\hline & $\mathrm{N}$ & $\%$ & $\mathrm{~N}$ & $\%$ & $\mathrm{~N}$ & $\%$ & $\mathrm{~N}$ & $\%$ & $\mathrm{~N}$ & $\%$ \\
\hline $\begin{array}{l}\text { Agricultural education } \\
\text { program is generally only } \\
\text { suited for unskilled work }\end{array}$ & 1 & 1.1 & 1 & 1.1 & 33 & 35.1 & 59 & 62.8 & 0 & .0 \\
\hline $\begin{array}{l}\text { Laboratory teaching and } \\
\text { shop activities appear to be } \\
\text { well organized }\end{array}$ & 37 & 39.4 & 51 & 54.3 & 5 & 5.3 & 0 & .0 & 1 & 1.1 \\
\hline $\begin{array}{l}\text { intended mainly for youth } \\
\text { of limited academic talent }\end{array}$ & 0 & .0 & 0 & .0 & 21 & 22.1 & 74 & 77.9 & 0 & .0 \\
\hline $\begin{array}{l}\text { develop leadership } \\
\text { abilities needed in } \\
\text { fulfilling occupational, } \\
\text { social, and civic } \\
\text { responsibilities }\end{array}$ & 56 & 58.9 & 36 & 37.9 & 2 & 2.1 & 1 & 1.1 & 0 & .0 \\
\hline
\end{tabular}


Table 16 (continued)

Guidance Counselor's Perceptions of How the Agriculture Education Programs Enrollment Affects Students

\begin{tabular}{|c|c|c|c|c|c|c|c|c|c|c|}
\hline & \multicolumn{2}{|c|}{$\begin{array}{l}\text { Strongly } \\
\text { Agree }\end{array}$} & \multicolumn{2}{|c|}{ Agree } & \multicolumn{2}{|c|}{ Disagree } & \multicolumn{2}{|c|}{$\begin{array}{l}\text { Strongly } \\
\text { Disagree }\end{array}$} & \multicolumn{2}{|c|}{$\begin{array}{c}\text { Not } \\
\text { Applicable }\end{array}$} \\
\hline & $\mathrm{N}$ & $\%$ & $\mathrm{~N}$ & $\%$ & $\mathrm{~N}$ & $\%$ & $\mathrm{~N}$ & $\%$ & $\mathrm{~N}$ & $\%$ \\
\hline $\begin{array}{l}\text { The course content could } \\
\text { fulfill course requirements } \\
\text { for some academic courses }\end{array}$ & 9 & 9.8 & 59 & 64.1 & 15 & 16.3 & 3 & 3.3 & 6 & 6.5 \\
\hline $\begin{array}{l}\text { should be allowed to count } \\
\text { for science credit needed } \\
\text { for graduation }\end{array}$ & 14 & 15.7 & 44 & 49.4 & 25 & 28.1 & 5 & 5.6 & 1 & 1.1 \\
\hline $\begin{array}{l}\text { place for students to learn } \\
\text { skills they can use in the } \\
\text { future }\end{array}$ & 51 & 53.7 & 44 & 46.3 & 0 & .0 & 0 & .0 & 0 & .0 \\
\hline $\begin{array}{l}\text { place for students to relax } \\
\text { from the pressures of the } \\
\text { regular class requirements } \\
\text { still learn new skills }\end{array}$ & 5 & 5.2 & 50 & 52.1 & 31 & 32.3 & 8 & 8.3 & 2 & 2.1 \\
\hline $\begin{array}{l}\text { develops premier } \\
\text { leadership in all their } \\
\text { students }\end{array}$ & 13 & 14.0 & 50 & 53.8 & 27 & 29.0 & 1 & 1.1 & 2 & 2.2 \\
\hline $\begin{array}{l}\text { develops career interests in } \\
\text { all their students }\end{array}$ & 7 & 7.7 & 51 & 56.0 & 32 & 35.2 & 0 & .0 & 1 & 1.1 \\
\hline
\end{tabular}

When guidance counselors were asked if they thought that "agricultural education develops premier leadership in all their students," 50 (53.8\%) responded that they agreed that it did develop leadership while 27 (29\%) disagreed. Thirteen respondents (14.0\%) strongly agreed that agricultural education develops premier leadership while one (1.1\%) 
respondent strongly disagreed and two $(2.2 \%)$ responded that it was not applicable (see Table 16).

Counselors were asked if "agricultural education develops career interests in all their students," 51 respondents $(56.0 \%)$ agreed that the program does develop some career interest while $32(35.2 \%)$ respondents disagreed. Seven (7.7 \%) respondents strongly agreed and one (1.1\%) felt that it was not applicable for the program to develop career interest in all their students (see Table 16).

\section{Guidance Counselors' Perceptions of How Students with IEP's Respond to Career and Technical Education Programs Especially Agricultural Education}

Guidance Counselors were asked to indicate their level agreement with the following statement “Student IEP's are an accurate reflection of the students' abilities and desires," 48 respondents (55.8\%), agreed with the statement, while $21(24.4 \%)$ disagreed. Seven $(8.1 \%)$ strongly agree that IEP's are an accurate reflection of a student's abilities and desires, while five each $(5.8 \%)$ responded they strongly disagreed and that this was not applicable, (see Table 17).

Counselors were asked about their level of agreement with the statement "agricultural education teachers are good at modifying program content for students with modifications listed in their IEP's. Sixty- two (69.7\%) of respondents agreed that agriculture teachers are good at modifying course content, 19 (21.3\%) strongly agreed, three (3.4\%) disagreed and five (5.6\%) responded not applicable, while none of the respondents strongly disagreed (see Table 17).

When presented with the statement "Students with learning disabilities must be enrolled in some career and technical education class to motivate them to graduate high 
school," 48 respondents (52.7\%) disagreed, 30 (33\%) agreed, six (6.6\%) strongly agreed, four (4.4\%) strongly disagreed and three (3.3\%) responded that this was not applicable that students with learning disabilities must be enrolled in some career and technical education class to motive them (see Table 17).

Table 17

Guidance Counselors' Perceptions of How Students with IEP's Respond to Career and Technical Education Programs Especially Agricultural Education.

\begin{tabular}{|c|c|c|c|c|c|c|c|c|c|c|}
\hline & \multicolumn{2}{|c|}{$\begin{array}{l}\text { Strongly } \\
\text { Agree }\end{array}$} & \multicolumn{2}{|c|}{ Agree } & \multicolumn{2}{|c|}{ Disagree } & \multicolumn{2}{|c|}{$\begin{array}{l}\text { Strongly } \\
\text { Disagree }\end{array}$} & \multicolumn{2}{|c|}{$\begin{array}{c}\text { Not } \\
\text { Applicable }\end{array}$} \\
\hline & $\mathrm{N}$ & $\%$ & $\mathrm{~N}$ & $\%$ & $\mathrm{~N}$ & $\%$ & $\mathrm{~N}$ & $\%$ & $\mathrm{~N}$ & $\%$ \\
\hline $\begin{array}{l}\text { IEP's are an accurate } \\
\text { reflection of the students' } \\
\text { abilities and desires }\end{array}$ & 7 & 8.1 & 48 & 55.8 & 21 & 24.4 & 5 & 5.8 & 5 & 5.8 \\
\hline $\begin{array}{l}\text { good at modifying } \\
\text { program content for } \\
\text { students with IEP's }\end{array}$ & 19 & 21.3 & 62 & 69.7 & 3 & 3.4 & 0 & .0 & 5 & 5.6 \\
\hline $\begin{array}{l}\text { Students with learning } \\
\text { disabilities must be } \\
\text { enrolled in some career } \\
\text { and technical education } \\
\text { class to motivate them to }\end{array}$ & 6 & 6.6 & 30 & 33.0 & 48 & 52.7 & 4 & 4.4 & 3 & 3.3 \\
\hline $\begin{array}{l}\text { Special education students } \\
\text { perform as well in } \\
\text { agricultural education } \\
\text { classes as they do in core } \\
\text { curriculum classes }\end{array}$ & 5 & 5.4 & 64 & 69.6 & 18 & 19.6 & 1 & 1.1 & 4 & 4.3 \\
\hline
\end{tabular}

When asked for their level with the statement "special education students perform as well in agriculture education classes as they do in core curriculum classes," 64 
respondents (69.6\%) agreed. Eighteen (19.6\%) respondents disagreed, five (5.4\%) strongly agreed, four $(4.3 \%)$ responded not applicable and one (1.1\%) strongly disagreed that special education students perform as well in agricultural education classes as they do in core curriculum classes (see Table 17).

\section{Guidance Counselors Perceptions of FFA Organization as it Pertains to the}

\section{Agricultural Curriculum}

Respondents were asked to indicate their level of agreement with the statement

"The FFA should be an integral part of the agricultural education program," 47 (49.5\%) respondents agreed and 45 (47.4\%) respondents strongly agreed to FFA being an integral part to the agriculture education curriculum. Two (2.1\%) disagreed and one (1.1\%) responded that it was not applicable (see Table 18).

When asked if "FFA membership should be required of every agricultural student," 56 (60.9\%) respondents disagreed, 15 (16.3\%) agreed, 12 (13.\%) strongly agree and four (4.3\%) strongly disagree. Five (5.4\%) responded, not applicable to FFA membership should be required of every agricultural student (see Table 18). 
Table 18

Guidance Counselors Perceptions of FFA Organization as it Pertains to the Agricultural Curriculum

\begin{tabular}{lccccccccccc}
\hline & \multicolumn{2}{c}{$\begin{array}{c}\text { Strongly } \\
\text { Agree }\end{array}$} & Agree & Disagree & $\begin{array}{c}\text { Strongly } \\
\text { Disagree }\end{array}$ & \multicolumn{2}{c}{$\begin{array}{c}\text { Not } \\
\text { Applicable }\end{array}$} \\
\cline { 2 - 12 } & $\mathrm{N}$ & $\%$ & $\mathrm{~N}$ & $\%$ & $\mathrm{~N}$ & $\%$ & $\mathrm{~N}$ & $\%$ & $\mathrm{~N}$ & $\%$ \\
\hline $\begin{array}{l}\text { The FFA integral part } \\
\text { TFA membership require }\end{array}$ & 45 & 47.4 & 47 & 49.5 & 2 & 2.1 & 0 & .0 & 1 & 1.1 \\
$\begin{array}{l}\text { FF every agricultural } \\
\text { education student }\end{array}$ & 12 & 13.0 & 15 & 16.3 & 56 & 60.9 & 4 & 4.3 & 5 & 5.4 \\
\hline
\end{tabular}

\section{Counselor's Methods for Scheduling Students in Agricultural Classes}

Counselors were asked if they believed that "above average students, even if interested in agricultural education, should be discouraged from enrolling in agricultural education programs, clothes," 74 (77.9\%) respondents strongly disagreed, and 21 (22.1\%) disagreed. No respondents, strongly agreed, agreed or responded not applicable (see Table 19).

When asked to respond to the statement "when developing student schedules I review their student interest survey," 53 respondents (55.8\%) agreed, 16 16.8\%) strongly agreed and $18(18.9 \%)$ responded that this was not applicable to their situation. Seven (7.4\%) respondents disagreed and one $(1.1 \%)$ strongly disagreed with the statement that they review the students' interest survey when developing schedules (see Table 19).

When the counselors were asked to indicate their level agreement with statement "when developing schedules for student with IEP's I review IEP documents to determine proper placement," 39 respondents (41.5\%) agreed that they reviewed the IEP, 31 (33\%) 
strongly agreed. Nineteen $(20.2 \%)$ responded that it was not applicable and five $(5.3 \%)$ respondents disagreed, none of the respondents strongly disagreed with reviewing the IEP to determine proper placement (see Table 19).

Respondents were asked to indicate their level agreement with the statement "earn a degree and graduate early (EDGE) credits are a major factor for placing students in agricultural education programs," $53(56.4 \%)$ respondents disagreed with the statement. That a student's ability to earn EDGE credits is a major factor for placing them in classes. Twenty-three (24.5\%) agreed, two (2.1\%) strongly agreed, eleven (11.7\%) strongly disagreed and five (5.3\%) responded that it was not applicable in their situation that the ability for a student to earn EDGE credits was not a factor in placing students in agricultural education classes (see Table 19)..

Guidance counselors were asked to indicate their level of agreement with the following statement, "our counseling department tends to advice students, regardless of academic record, to consider enrolling in agricultural education classes,"54(57.4\%) respondents agreed and $17(18.1 \%)$ strongly agreed with statement Nineteen $(20.2 \%)$ respondents disagreed, while four (4.3\%) indicated it was not applicable and none of the respondents strongly disagreed (See Table 19).

When enrolling students into agricultural education classes counselors were asked to respond to the statement, "our counseling department tends to advise students, regardless of future college, or work plans, to consider enrolling in agricultural education classes," $52(58.4 \%)$ respondents agreed and $11(12.4 \%)$ strongly agreed statement. Twenty-two (24.7\%) respondents disagreed, three (3.4\%) respondents strongly disagreed, while one (1.1\%) choose not applicable (see Table 19). 
When asked, "if a college bound student expresses interest in an agricultural education course our guidance department tends to advise him/her to enroll," 49 (51.0\%) respondents agreed and $45(46.9 \%)$ strongly agreed. Two $(2.1 \%)$ disagreed and none of the applicants strongly disagreed or responded not applicable (see Table 19).

Table 19

Counselor's Methods for Scheduling Students in Agricultural Classes.

\begin{tabular}{|c|c|c|c|c|c|c|c|c|c|c|}
\hline & \multicolumn{2}{|c|}{$\begin{array}{l}\text { Strongly } \\
\text { Agree }\end{array}$} & \multicolumn{2}{|c|}{ Agree } & \multicolumn{2}{|c|}{ Disagree } & \multicolumn{2}{|c|}{$\begin{array}{l}\text { Strongly } \\
\text { Disagree }\end{array}$} & \multicolumn{2}{|c|}{$\begin{array}{c}\text { Not } \\
\text { Applicable }\end{array}$} \\
\hline & $\mathrm{N}$ & $\%$ & $\mathrm{~N}$ & $\%$ & $\mathrm{~N}$ & $\%$ & $\mathrm{~N}$ & $\%$ & $\mathrm{~N}$ & $\%$ \\
\hline $\begin{array}{l}\text { Above average students, } \\
\text { should be discouraged } \\
\text { from enrolling in } \\
\text { agricultural education } \\
\text { programs }\end{array}$ & 0 & .0 & 0 & .0 & 21 & 22.1 & 74 & 77.9 & 0 & .0 \\
\hline $\begin{array}{l}\text { I review their student } \\
\text { interest survey }\end{array}$ & 16 & 16.8 & 53 & 55.8 & 7 & 7.4 & 1 & 1.1 & 18 & 18.9 \\
\hline $\begin{array}{l}\text { I review the IEP } \\
\text { documents to determine } \\
\text { proper placement }\end{array}$ & 31 & 33.0 & 39 & 41.5 & 5 & 5.3 & 0 & .0 & 19 & 20.2 \\
\hline $\begin{array}{l}\text { Earn a Degree and } \\
\text { Graduate Early (EDGE) } \\
\text { credits are a major factor } \\
\text { for placing students }\end{array}$ & 2 & 2.1 & 23 & 24.5 & 53 & 56.4 & 11 & 11.7 & 5 & 5.3 \\
\hline $\begin{array}{l}\text { Our counseling } \\
\text { department tends to } \\
\text { advise students, } \\
\text { regardless of academic } \\
\text { record }\end{array}$ & 17 & 18.1 & 54 & 57.4 & 19 & 20.2 & 0 & .0 & 4 & 4.3 \\
\hline
\end{tabular}


Table 19 (continued)

Counselor's Methods for Scheduling Students in Agricultural Classes.

\begin{tabular}{|c|c|c|c|c|c|c|c|c|c|c|}
\hline & \multicolumn{2}{|c|}{$\begin{array}{c}\text { Strongly } \\
\text { Agree }\end{array}$} & \multicolumn{2}{|c|}{ Agree } & \multicolumn{2}{|c|}{ Disagree } & \multicolumn{2}{|c|}{$\begin{array}{l}\text { Strongly } \\
\text { Disagree }\end{array}$} & \multicolumn{2}{|c|}{$\begin{array}{c}\text { Not } \\
\text { Applicable }\end{array}$} \\
\hline & $\mathrm{N}$ & $\%$ & $\mathrm{~N}$ & $\%$ & $\mathrm{~N}$ & $\%$ & $\mathrm{~N}$ & $\%$ & $\mathrm{~N}$ & $\%$ \\
\hline $\begin{array}{l}\text { advise students, } \\
\text { regardless of future } \\
\text { college or work plans, to } \\
\text { consider enrolling in } \\
\text { agricultural education } \\
\text { classes }\end{array}$ & 11 & 12.4 & 52 & 58.4 & 22 & 24.7 & 3 & 3.4 & 1 & 1.1 \\
\hline $\begin{array}{l}\text { college bound student } \\
\text { expresses interest in an } \\
\text { agricultural education } \\
\text { course our guidance } \\
\text { department tends to } \\
\text { advise }\end{array}$ & 45 & 46.9 & 49 & 51.0 & 2 & 2.1 & 0 & .0 & 0 & .0 \\
\hline $\begin{array}{l}\text { should be included in the } \\
\text { scheduling process of } \\
\text { their current students }\end{array}$ & 17 & 18.3 & 63 & 67.7 & 10 & 10.8 & 0 & .0 & 3 & 3.2 \\
\hline $\begin{array}{l}\text { Students with learning } \\
\text { disabilities are enrolled to } \\
\text { give them a positive adult } \\
\text { role model }\end{array}$ & 0 & .0 & 29 & 33.7 & 46 & 53.5 & 3 & 3.5 & 8 & 9.3 \\
\hline
\end{tabular}

Guidance Counselors when asked if, "agricultural education teachers should be involved in the scheduling process of their current students," $63(67.7 \%)$ respondents agreed and $17(18.3 \%)$ strongly agreeing. While 10(10.8\%) disagreed, three $(3.2 \%)$ responded it was not applicable and none of the respondents strongly disagreed with statement (see Table 19).

Guidance counselors were asked to indicate your level agreement with the following statement, "Students with learning disabilities are enrolled in agricultural 
education give them a positive adult role model." Forty-six (53.5\%) disagreed that this was a motive for them enrolling special education students in agricultural classrooms, 29 agreed (33.7\%), eight (9.3\%) responded that this was not applicable, three $(3.5 \%)$ strongly disagreed and none of the respondents indicated that they strongly agreed with the statement (see Table 19).

\section{Guidance Counselors Understanding of How They Affect Programs in Their School}

When counselors were asked to indicate their level of agreement with statement,

"A student being able to complete a career and technical program is a critical factor in scheduling students," 61 (64.9\%) respondents agreed, 20 (21.3\%) strongly agreed. Ten $(10.6 \%)$ respondents disagreed, one $(1.1 \%)$ strongly disagreed and two $(2.1 \%)$ responded that this was not applicable (see Table 20).

Respondents were asked to indicate their level of agreement with the following statement, "Perkins funding is determined by the number of completers a program graduates," $34(44.2 \%)$ respondents agreed, and 16 (20.8\%) strongly agreed. Eighteen (23.4\%) responded it was not applicable not applicable, while six (7.8\%) respondents disagreed and three (3.9\%) strongly disagreed that Perkins funding is not determined by the number of completers a program graduates (see Table 20).

Guidance counselors asked to indicate their level of agreement with the following statement, "Perkins funding is not important to Career and Technical Education programs including agricultural education in West Virginia", 39 respondents strongly disagreed, while $31(37.8 \%)$ respondents disagreed with statement. Ten (12.2\%) respondents indicated it was not applicable and one (1.2\%) agreed and one (1.2\%) respondent 
strongly agreed that Perkins funding is not important to Career and Technical education programs in West Virginia (see Table 20).

Table 20

Guidance Counselors Understanding of How They Affect Programs in Their School

\begin{tabular}{|c|c|c|c|c|c|c|c|c|c|c|}
\hline & \multicolumn{2}{|c|}{$\begin{array}{l}\text { Strongly } \\
\text { Agree }\end{array}$} & \multicolumn{2}{|c|}{ Agree } & \multicolumn{2}{|c|}{ Disagree } & \multicolumn{2}{|c|}{$\begin{array}{l}\text { Strongly } \\
\text { Disagree }\end{array}$} & \multicolumn{2}{|c|}{$\begin{array}{c}\text { Not } \\
\text { Applicable }\end{array}$} \\
\hline & $\mathrm{N}$ & $\%$ & $\mathrm{~N}$ & $\%$ & $\mathrm{~N}$ & $\%$ & $\mathrm{~N}$ & $\%$ & $\mathrm{~N}$ & $\%$ \\
\hline $\begin{array}{l}\text { A student being able to } \\
\text { complete a career and } \\
\text { technical program critical } \\
\text { in scheduling students }\end{array}$ & 20 & 21.3 & 61 & 64.9 & 10 & 10.6 & 1 & 1.1 & 2 & 2.1 \\
\hline $\begin{array}{l}\text { Perkins funding is } \\
\text { determined by the number } \\
\text { of completers a program } \\
\text { graduates }\end{array}$ & 16 & 20.8 & 34 & 44.2 & 6 & 7.8 & 3 & 3.9 & 18 & 23.4 \\
\hline $\begin{array}{l}\text { Perkins funding is not } \\
\text { important to Career and } \\
\text { Technical Education } \\
\text { programs including } \\
\text { agricultural education in } \\
\text { WV }\end{array}$ & 1 & 1.2 & 1 & 1.2 & 31 & 37.8 & 39 & 47.6 & 10 & 12.2 \\
\hline $\begin{array}{l}\text { When scheduling } \\
\text { conflicts occur, our } \\
\text { counseling department } \\
\text { tends to advise non } \\
\text { college bound students }\end{array}$ & 2 & 2.3 & 22 & 25.3 & 46 & 52.9 & 12 & 13.8 & 5 & 5.7 \\
\hline
\end{tabular}

When asked to respond to the following statement, "When scheduling conflicts occur, our department of counseling tends to advise non-college bound students to consider enrolling in agricultural education courses as supposed to non-required academic courses," $46(52.9 \%)$ respondents disagreed and $12(13.8 \%)$ respondents 
strongly disagreed with statement. Twenty-Two (25.3\%) respondents agreed, two $(2.3 \%)$ strongly agreed that when scheduling conflicts occur they tend to advise non-college bound students to consider agricultural education classes, while five (5.7\%) respondents did not see the statement as applicable (see Table 20).

\section{Guidance Counselors Understanding of Course Content and Requirements}

Guidance Counselors were asked to indicate their level of agreement with the statement "I am knowledgeable about the course content, objectives and nature of instruction in our agricultural education classes,". 59 (65.6\%) respondents agreed, while $16(17.8 \%)$ strongly agreed. T. Thirteen $(14.4 \%)$ respondents disagreed and one $(1.1 \%)$ strongly disagreed, and one $(1.1 \%)$ respondent indicated it was not applicable that they had knowledge the course content, objectives and nature of instruction in their agricultural education classes (see Table 21).

Counselors were asked to indicate their level of the following statement, "Career and technical education programs are funded based on the number of completers, testing statistics, and job placements." that each course generates. Counselors responded that 47 $(61.0 \%)$ agreed with the statement, while 12 (15.6\%) strongly agreed, nine $(11.7 \%)$ respondents disagreed and nine $(11.7 \%)$ respondents did not see it as applicable to their situation (see Table 21). 
Table 21

Guidance Counselors Understanding of Course Content and Requirements.

\begin{tabular}{|c|c|c|c|c|c|c|c|c|c|c|}
\hline & \multicolumn{2}{|c|}{$\begin{array}{c}\text { Strongly } \\
\text { Agree }\end{array}$} & \multicolumn{2}{|c|}{ Agree } & \multicolumn{2}{|c|}{ Disagree } & \multicolumn{2}{|c|}{$\begin{array}{l}\text { Strongly } \\
\text { Disagree }\end{array}$} & \multicolumn{2}{|c|}{$\begin{array}{c}\text { Not } \\
\text { Applicable }\end{array}$} \\
\hline & $\mathrm{N}$ & $\%$ & $\mathrm{~N}$ & $\%$ & $\mathrm{~N}$ & $\%$ & $\mathrm{~N}$ & $\%$ & $\mathrm{~N}$ & $\%$ \\
\hline $\begin{array}{l}\text { Knowledgeable about the } \\
\text { course content, objectives } \\
\text { and nature of instruction } \\
\text { in our agricultural } \\
\text { education classes }\end{array}$ & 16 & 17.8 & 59 & 65.6 & 13 & 14.4 & 1 & 1.1 & 1 & 1.1 \\
\hline $\begin{array}{l}\text { Career and technical } \\
\text { education programs are } \\
\text { funded based on the } \\
\text { number of completers, } \\
\text { testing statistics, and job } \\
\text { placements }\end{array}$ & 12 & 15.6 & 47 & 61.0 & 9 & 11.7 & 0 & .0 & 9 & 11.7 \\
\hline
\end{tabular}

\section{Guidance Counselors’ Perceptions of Students’ Interest and Success}

Guidance counselors were asked if "students' interests and goals change each year," $54(59.3 \%)$ respondents agreed, while 17 (18.7\%) respondents strongly agreed. Nineteen (20.9\%) respondents disagreed that students' interests and goals changed each year, no respondents strongly disagreed, while one respondent indicated that it was not applicable (see Table 22).

Respondents were asked if they thought "students should be given an interest survey each year before scheduling," 44 (47.3\%) respondents disagreed, while thirtythree $(35.5 \%)$ agreed. Eight $(8.6 \%)$ respondents strongly disagreed, and seven $(7.5 \%)$ strongly agreed that students should be given an interest survey each year before scheduling, while one (1.1\%)respondent indicated it was not applicable (see Table 22). 
Guidance counselors were asked to get their impression of the statement, "Students who are successful in an agricultural education class are also successful in their core curriculum classes," 48 (54.5\%) counselors disagreed while 33 (37.5\%) agreed with statement. Five (5.7\%) responded it was not applicable not applicable, and one respondent (1.1\%) strongly agreed and one (1.1\%) respondent strongly disagreed (see Table 22).

Table 22

Guidance Counselors’ Perceptions of Students’ Interest and Success

\begin{tabular}{|c|c|c|c|c|c|c|c|c|c|}
\hline \multicolumn{2}{|c|}{$\begin{array}{c}\text { Strongly } \\
\text { Agree }\end{array}$} & \multicolumn{2}{|c|}{ Agree } & \multicolumn{2}{|c|}{ Disagree } & \multicolumn{2}{|c|}{$\begin{array}{l}\text { Strongly } \\
\text { Disagree }\end{array}$} & \multicolumn{2}{|c|}{$\begin{array}{c}\text { Not } \\
\text { Applicable }\end{array}$} \\
\hline $\mathrm{N}$ & $\%$ & $\mathrm{~N}$ & $\%$ & $\mathrm{~N}$ & $\%$ & $\mathrm{~N}$ & $\%$ & $\mathrm{~N}$ & $\%$ \\
\hline
\end{tabular}

Students' interests and goals change each year

$\begin{array}{llllllllll}17 & 18.7 & 54 & 59.3 & 19 & 20.9 & 0 & .0 & 1 & 1.1\end{array}$

Should be given an interest survey each year before scheduling $\begin{array}{lllllll}7 & 7.5 & 33 & 35.5 & 44 & 47.3 & 8\end{array}$ 8.61 1.1

Students who are successful in an agricultural education class are successful in their core curriculum classes

$\begin{array}{llllllllll}1 & 1.1 & 33 & 37.5 & 48 & 54.5 & 1 & 1.1 & 5 & 5.7\end{array}$




\section{CHAPTER 5}

\section{Summary, Conclusions, and Recommendations}

\section{Purpose of the Study}

The purpose of this study was to determine the methods that guidance or vocational counselors in West Virginia public schools use to schedule students into agricultural education programs in their school. This study will help teachers understand how guidance counselors schedule students and help diffuse the perceptions that counselors do not value agricultural education program. By understanding what factors impact student placement in career and technical education programs by guidance counselors and how to better create channels of communications between the counselors and the teachers.

\section{Research Questions}

The following research questions will guide the study:

1. What criteria determines student placement in career and technical education programs?

2. How do you determine which students will be placed in each career and technical education program?

3. Are Individualized Education Plans for Special Needs students reviewed by counselors to determine which career and technical education program would best suit the student?

4. What characteristics make career and technical education popular choices with students in West Virginia? 
5. Does completer's certification or EDGE credits make a difference in scheduling students?

6. How much does a guidance counselor understand about career and technical education funding and guidelines?

\section{Summary}

The demographics of the guidance counselors suggest that many are older women and have been a counselor either for less than ten years or for more than 20 years but are older than 24 years of age. An overwhelming majority of counselors were white. A majority of the counselors do not live on a farm but live in a rural setting. While they do live in a rural setting results indicated that a majority of the counselors were not involved with the agricultural education program and do not understand the benefits of agricultural education. Most of the respondents do not report a strong agricultural background and were not involved with the 4-H or FFA programs as a youth.

Most counselors indicated their schools have less than 250 students on individualized education plans. This can be attributed to the population size of the high schools, considering most schools in WV have less than 619 students. A majority of the respondents agreed that the reason that they schedule students into agricultural education classes was because the student expressed an interest, followed by the student's ability to be completers in the program.

Counselors agreed that agriculture teachers are helpful to other teachers and are concerned for the success of their students, including learning and mastering CSO's. Agricultural teachers are firm believer in their programs and strive to maintain, and increase the enthusiasm of their students in their studies. Counselors indicated that they 
see the agriculture teacher as being involved and interested in the development of the total student. While they were seemingly positive of agriculture teachers, they did not view agricultural teachers as having higher expectations of their students than other teachers.

Many counselors indicated they felt that agricultural teachers should help with scheduling their students and those they have great success with, including students on Individualized education plans. Counselors did not see the EDGE credit as a factor for placing students into the agricultural education program. A majority of the counselors overwhelming agreed that they are advising students to enroll in agricultural education classes regardless of future college or work plans. They also reported that they encourage students to enroll in agricultural education programs even if they are college bound.

Over half of the counselors strongly disagreed that graduates of agricultural education are only suitable for unskilled work. A majority of the counselors agreed that students develop leadership skills and skills for their future in the agricultural classroom. Counselors indicated that they believed that agricultural classes should count as course content for some academic course. Agricultural classes were viewed as a place that students can relax and that they are learning new skills they can use in the future, while teachers are developing career interests and premier leadership in their students

Counselors reported that students with IEP's appear to perform as well in agricultural education classes as they do regular education classes. However, the counselors were in overwhelming agreement that Agriculture teachers are good at modifying the program content for students with IEP's. There was a heavy split on 
whether counselors agreed or disagreed that students with disabilities needed to be enrolled in a career and technical education program. Counselors reported that FFA is an integral part of the Agriculture curriculum but that membership should not be required. While most respondents agreed that reviewing the IEP was used in scheduling, a small portion of the counselors indicated that it was not applicable to use the IEP when scheduling students. An overwhelming majority of the counselors agreed that the Agriculture teacher should be involved in helping to schedule their current students.

Counselors were in overwhelming disagreement with the statement that they discouraged above average students from enrolling agriculture classes. In addition, they overwhelmingly agreed that college bound students were advised to enroll in agricultural classes. They do review interest surveys and IEPs before scheduling students and that there is no regard to academic record when scheduling.

Respondents did indicate that a student being a completer was critical to scheduling and that the number of completers is critical to Perkins Funding. Counselors agree that they have knowledge of the course content of their schools programs but could not identify the programs of studies that the completers would be completing.

When reviewing the data one can see that the criteria that is used to place students in career and technical education revolves around the students interest in the subject, while many believed that students interests change and goals change each year but do not indicate that an interest survey should be given to students each year.

\section{Conclusions}

Based on the findings one can conclude that counselors are scheduling students into agricultural education programs regardless of the students academic and career plans. 
Counselors report that students with IEP's can be just as successful in agricultural classes as they are in their other classes. While counselors are not fully aware of all facets of the agricultural program, they respect the agricultural instructors and the program. It is apparent that counselors are split on the concept on if students should fill out an interest survey before scheduling each year, because they were split on the idea that students interest change each year.

Counselors view agricultural teachers as concerned for students' achievement and personal growth. Counselors report that they do enroll students in agricultural education classes because the student expressed an interest, and because the students have the ability to be a completer in the program. Individualized education plans while being a reflection of student's educational levels and student goals are the reason for the students' success in school show that students enrolled in agricultural education perceive that the student has greater student achievement and personal growth. This perception of achievement and personal growth is accomplished by agricultural teachers motivating the students, through communication and assisting the students with career and guidance counseling issues, the perception is overwhelming, that agriculture teachers are involved and interested in developing their students, by using a variety of teaching techniques. Counselors also agreed that agricultural classes could be use to fulfill course requirements for other academic courses and that agricultural classes help fulfill the social, civic leadership abilities of the student. Counselors do not perceive a student with IEP as having parents that are actively involved in the academic success of the students. It must be noted that while many counselors agreed that agriculture teachers work well with students with IEP's, that is not a reason to schedule students with an IEP into their 
program. Counselors reported that students learning and mastering course content as a critical factor in student success. It can also be concluded if students' interests are changing then they need to be evaluated to determine how their educational path should proceed.

\section{Recommendations}

1. Agriculture teachers must continue to promote their program, track their students and assist in the scheduling process to allow students to properly complete their desired program area. They must also continue to be enthusiastic about their student's achievements.

2. Agriculture teachers must continually communicate with counselors when education program changes are made in their programs, which include basic changes such as course names, numbers and other directives from the state department.

3. Agriculture teachers must become advocates for their programs, by inviting counselors to events, programs and show their gratitude for the counselors work and assistance. Agriculture teachers need to develop and maintain positive relationships with counselors at their school and feeder schools to make the transition of students into their programs smooth and seamless.

4. Agriculture teachers need to be included in Individualized education plan meetings for all students that are potential completers in their courses so they explain the importance to the parent, student, and others attending the meeting. Teachers should encourage students to request that being completers is a goal that should be reflected on their IEP. This will help in developing parents and 
student's interest in the program and opening communication between the instructor and the parents.

5. Agriculture teachers need to continue to develop and foster the enthusiasm for their program, attend or host open houses for potential students.

6. Agriculture teachers need to maintain an open dialogue with the counselors so schedule adjustments can be made early.

7. Further studies on guidance counselor's perceptions of agricultural education programs needs to be conducted. 


\section{REFERENCES}

American School Counselor Association, (2009). The role of the professional school counselor. (2009). Retrieved from http://www.schoolcounselor.org/content.asp?pl=325\&sl=133\&contentid=240

Ary, D., Jacobs L.C., Razavieh, A., \& Sorensen, C. (2006). Introduction to research in education, (7th ed.). Belmont: Thompson and Wadsworth.

Carl D. Perkins Career and Technical Education Improvement Act of 2006. Pub. L. No. 109-270, 20 USC 2301. (2006). Retrieved from http://www.gpo.gov/fdsys/pkg/PLAW-109publ270/htm1/PLAW-109publ270.htm

Dillman, D. A. (2000). Mail and internet surveys: The tailored design method ( $2^{\text {nd }}$ ed.). New York: Wiley.

Dyer, J., \& Osborne, E. W. (1999). The influence of science applications in agriculture courses on attitudes of Illinois guidance couselors at model student teaching centers. Journal of Agricultural Education, 57-66.

Federal Education Policy History. (2011, February, \#109). Retrieved from http://federaleducationpolicy.wordpress.com/2011/02/19/1917

Feller, R. (1994). School counselor role in planning and integrating basic skills. Eric Digest.

Hoover, T. (1991). Enrollment issues in agriculutral education programs and FFA membership. Journal of Agricultural Education, 2-10.

Martin, M. J., Fritzsche, J. A., \& Ball, A. L. (2006). A delphi study of teachers' and professionals' perceptions regarding the impact of the No Child Left Behind legislation on secondary agricultural education programs. Journal of Agricultural Education, 100-109.

McGee, M. B, \& Bender, R. E. (1975). Attitudes of administrators and guidance counselors regarding vocational agriculture. Retrieved September 12, 2008, from ERIC database.

Myers, B. E., Dyer, J. E., \& Breja, L. M. (2003). Recruitment strategies and activities used by agriculture teachers. Journal of Agricultural Education , 94-105. 
National Research Council (1988). Understanding agriculture: new directions for education. (First Ed., Vol. 1). Washington, DC: National Academy Press. Retrieved from:

http://books.google.com/books?id=S2MrAAAAYAAJ\&printsec=frontcover\&dq= inauthor:"National Research Council (U.S.). Board on Agriculture. Committee on Agricultural Education in Secondary Schools"\&hl=en\&sa=X\&ei=48fxUYPyOOf94AOBoG4DQ\&ved=0CDIQuwUwAA

Patterson, S. (n.d.). Smith-Hughes Act of 1917 (pl 347). Retrieved from http://jschell.myweb.uga.edu/history/legis/smithughes.htm

University of Georgia Cooperative Extension Service. (n.d.) Changes in U.S. agriculture; from the 1950's to the 1990's. Retrieved from http://www.ces.uga.edu/Agriculture/agecon/pubs/agric50-90.htm

U.S. Department of Education, (2002). The Carl D. Perkins Vocational and Technical Education Act, Public Law 105-332. Retrieved from http://www2.ed.gov/offices/OVAE/CTE/perkins.html

U.S, Department of Education, (2007) FY 2007 Allocations for Carl D. Perkins Career and Technical Act of 2006. (2007, 06 27). Retrieved from http://www2.ed.gov/programs/ctesbg/07allot.html

Robinson, J.P., Shaver, P.R., \& Wrightsman, L.S. (1991). Criteria for scale selection and evaluation in J.P. Robinson, P.R. Shaver \&L.S. Wrightsman (Eds.) Measurers of personality and social psychological attitudes. New York: Academic Press.

Schafer, S. (2011, May). Strong job outlook for agriculture. AgWeb. Retrieved from http://www.agweb.com/article/strong_job_outlook_for_agriculture_/

Spielmaker, D. (n.d.). Growing a nation: The story of American agriculture. Retrieved from http://www.agclassroom.org/gan/timeline/1900.htm

Sutphin, H. D. (1995). Student's rationale for selection of agriculturally related courses in his school by gender and ethniticity. Journal of Agricultural Education, 54-61.

Thompson, J. C. (1993). Beliefs and intentions of counselors, parents, and students regarding agriculture as a career choice. Journal of Agricultural Education , 5563.

West Virginia Department of Education, (n.d.a) West Virginia school counseling programs. Retrieved from http://wvde.state.wv.us/counselors/

West Virginia Department of Education, (n.d.b) School counseling: Guidance curriculum. Retrieved from: http://wvde.state.wv.us/counselors/guidancecurriculum.html 
West Virginia Department of Education (n.d. c.) Curricula. Retrieved from: http://careertech.k12.wv.us/edge/curricula.htm

West Virginia Department of Education (n.d. d.).Resources. Retrieved from http://wvde.state.wv.us/riseup/resources.php 
APPENDIX A

Cover Letter 
February 2, 2009

Dear «sir name»«last name»:

West Virginia Agriculture Teachers are frequently asked the question, "Why do you think students continue to be enrolled in agricultural programs?" There are multitudes of answers that teachers will give, but never can we attribute why you place those students with us. You are the valuable resource that keeps our programs successful. Thank you.

I am Nicole Riggle Shipman, a graduate student in Agricultural and Extension Education at West Virginia University and have been an Agricultural Teacher at John Marshall High School for the past 8 years. Under the direction of my advisor, Dr.

Deborah A. Boone, I am conducting a research study to determine the knowledge of West Virginia Guidance Counselors on state and federal guidelines and the process of scheduling special education students in Agricultural Education Programs in the State of West Virginia. The results of this study will be used to prepare a thesis to partially fulfill the requirements for a Master's of Science degree in Agricultural and Extension Education. West Virginia University's IRB acknowledgment of this research study is on file.

Your participation in this research study is completely voluntary. You may stop filling out this survey at any time or skip any question you do not wish to answer. However, your completion of this survey is crucial to the success of this study. The survey should only take about 15 minutes and your results will be held as confidential as possible. There is no penalty if you choose not to participate. You will notice a code number at the bottom left-hand corner of your return envelope. This number is only used to keep track of non-respondents and will be destroyed before the data is analyzed, making it in no way possible to track your individual response.

Please place the completed questionnaire in the self-addressed prepaid envelope and drop it in the mail box by March 1, 2009. Thank you for your assistance. We sincerely appreciate your time and dedication to the students of our fine State.

Sincerely,

Nicole Riggle Shipman

Deborah A. Boone, PhD

Graduate Student

Assistant Professor 
APPENDIX B

Survey Instrument 
Knowledge of West Virginia Guidance Counselors on State and Federal

Guidelines and the Process of Scheduling Special Education Students in

Agricultural Education Programs in the State of West Virginia.

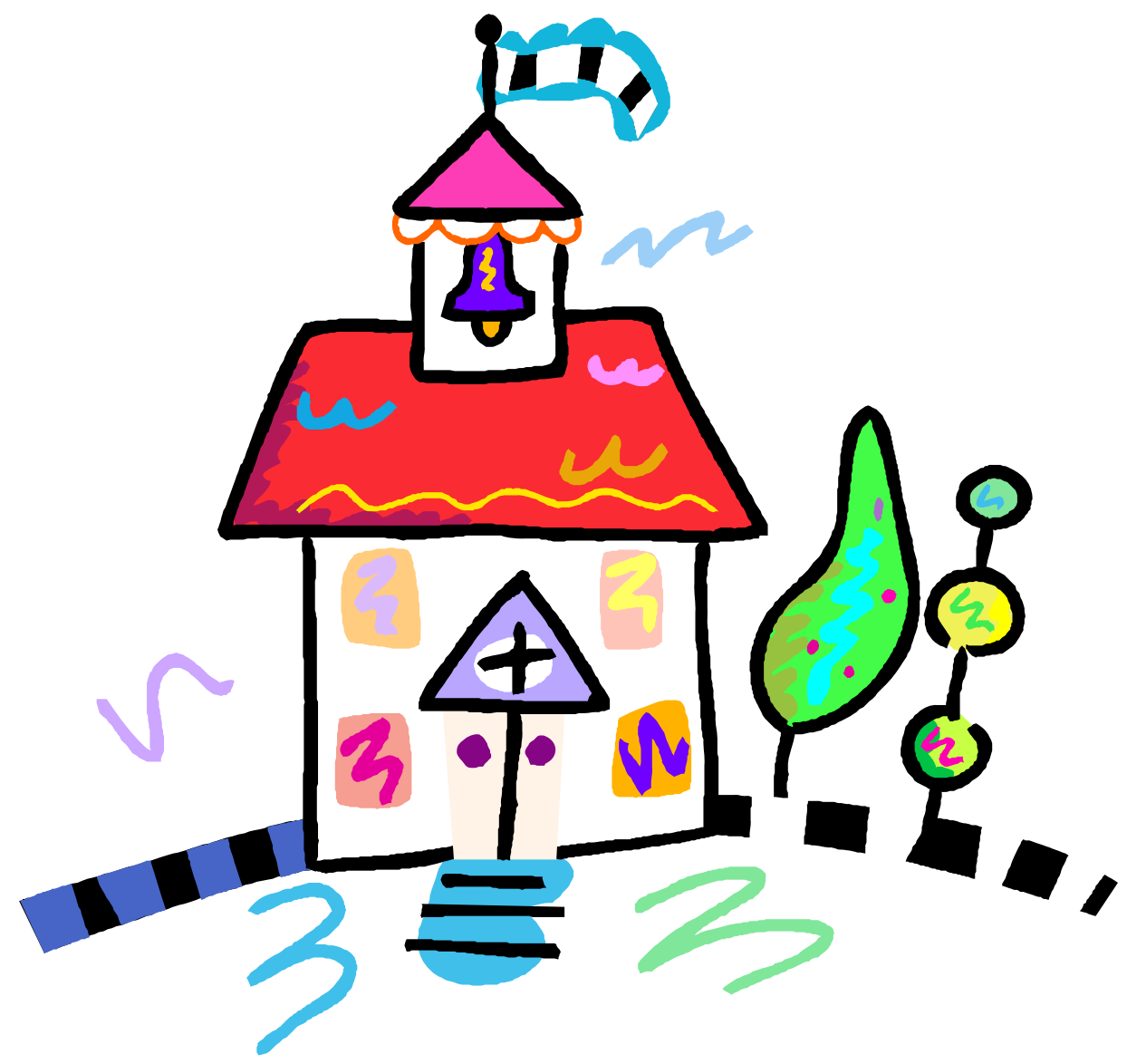

Nicole Riggle Shipman

Graduate Student

Agricultural and Extension Education

Davis College of Agriculture, Forestry, and Consumer Sciences

West Virginia University

Morgantown, WV 26506 


\section{Knowledge of West Virginia Guidance Counselors on State and Federal Guidelines and the Process of Scheduling Special Education Students in Agricultural Education Programs in the State of West Virginia.}

Instructions: Read each of the following statements and indicate your response by circling the response the closest to your true feelings about each statement. SA - strongly agree, A - Agree, D- Disagree, SD - Strongly Disagree, NA - Not applicable to my school.

\begin{tabular}{|c|c|c|c|c|c|c|}
\hline & Statement & 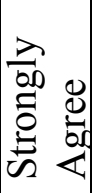 & 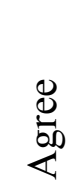 & 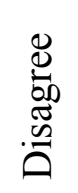 & 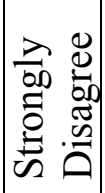 & 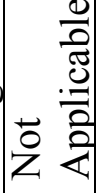 \\
\hline 1 & $\begin{array}{l}\text { Agricultural education teachers are firm believers in } \\
\text { the worth and value of their programs. }\end{array}$ & SA & A & $\mathrm{D}$ & SD & NA \\
\hline 2 & $\begin{array}{l}\text { In my opinion a graduate of a high school agricultural } \\
\text { education program is generally only suited for } \\
\text { unskilled work. }\end{array}$ & SA & A & $\mathrm{D}$ & SD & NA \\
\hline 3 & $\begin{array}{l}\text { Agricultural education programs teachers I have } \\
\text { known seek to maintain and increase the enthusiasm of } \\
\text { their students for their studies. }\end{array}$ & SA & A & D & SD & NA \\
\hline 4 & $\begin{array}{l}\text { Agricultural education teachers are not able to } \\
\text { communicate effectively with individuals not directly } \\
\text { related to agriculture. }\end{array}$ & SA & A & D & SD & NA \\
\hline 5 & $\begin{array}{l}\text { Agricultural education teachers I have known tend to } \\
\text { be less cooperative than other teachers in the school. }\end{array}$ & SA & A & $\mathrm{D}$ & SD & NA \\
\hline 6 & $\begin{array}{l}\text { Agricultural education teachers I have known seem to } \\
\text { go out of their way to help other teachers in the school. }\end{array}$ & $\mathrm{SA}$ & A & D & SD & NA \\
\hline 7 & $\begin{array}{l}\text { Laboratory teaching and shop activities of agricultural } \\
\text { education that I have known appear to be well } \\
\text { organized. }\end{array}$ & SA & A & D & SD & NA \\
\hline 8 & $\begin{array}{l}\text { Above average students, even if interested in } \\
\text { agricultural education, should be discouraged from } \\
\text { enrolling in these programs. }\end{array}$ & SA & A & $\mathrm{D}$ & SD & NA \\
\hline 9 & $\begin{array}{l}\text { Agricultural education programs in high school should } \\
\text { be intended mainly for youth of limited academic } \\
\text { talent. }\end{array}$ & $\mathrm{SA}$ & A & $\mathrm{D}$ & SD & NA \\
\hline 10 & $\begin{array}{l}\text { The FFA should be an integral part of the vocational } \\
\text { agricultural program. }\end{array}$ & SA & A & $\mathrm{D}$ & SD & NA \\
\hline 11 & $\begin{array}{l}\text { Agricultural education teachers seem to be involved } \\
\text { and interested in the development of the total student. }\end{array}$ & SA & A & $\mathrm{D}$ & SD & NA \\
\hline 12 & $\begin{array}{l}\text { Agricultural education programs develop leadership } \\
\text { abilities needed in fulfilling occupational, social, and } \\
\text { civic responsibilities. }\end{array}$ & $\mathrm{SA}$ & A & $\mathrm{D}$ & SD & NA \\
\hline
\end{tabular}




\begin{tabular}{|c|c|c|c|c|c|c|}
\hline 13 & $\begin{array}{l}\text { When developing student schedules we review their } \\
\text { student interest survey. }\end{array}$ & SA & A & D & SD & $\mathrm{NA}$ \\
\hline 14 & $\begin{array}{l}\text { When developing schedules for student with IEP's we } \\
\text { review the IEP documents to determine proper } \\
\text { placement. }\end{array}$ & SA & A & D & SD & $\mathrm{NA}$ \\
\hline 15 & $\begin{array}{l}\text { Earn a Degree and Graduate Early (EDGE) credits are } \\
\text { a major factor for placing students in agricultural } \\
\text { programs. }\end{array}$ & SA & A & D & SD & NA \\
\hline 16 & $\begin{array}{l}\text { A student being able to complete a career and technical } \\
\text { program is a critical factor in scheduling students. }\end{array}$ & SA & A & D & SD & $\mathrm{N} A$ \\
\hline 17 & uates. & SA & $\mathrm{A}$ & $\mathrm{D}$ & SD & $\overrightarrow{\mathrm{NA}}$ \\
\hline 18 & $\begin{array}{l}\text { Perkins funding is not important to Career and } \\
\text { Technical Education programs including Agricultural } \\
\text { Education in West Virginia. }\end{array}$ & SA & A & D & SD & $\mathrm{NA}$ \\
\hline 19 & $\begin{array}{l}\text { It is a agricultural education teachers job to develop } \\
\text { and help in guidance with students in agricultural } \\
\text { related areas. }\end{array}$ & SA & A & $\mathrm{D}$ & SD & A \\
\hline 20 & $\begin{array}{l}\text { The course content offered in an agricultural education } \\
\text { program could fulfill course requirements for some } \\
\text { academic courses. }\end{array}$ & SA & A & D & SD & NA \\
\hline 21 & 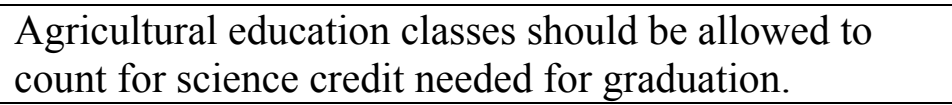 & SA & A & $\mathrm{D}$ & SD & NA \\
\hline 22 & $\begin{array}{l}\text { ds to advise students, } \\
\text { to consider enrolling in }\end{array}$ & SA & A & D & SD & $\mathrm{NA}$ \\
\hline 23 & $\begin{array}{l}\text { ur, our counseling } \\
\text { college bound students } \\
\text { ltural Education courses } \\
\text { demic courses. }\end{array}$ & SA & $\mathrm{A}$ & L & $\mathrm{D}$ & NA \\
\hline 24 & $\begin{array}{l}\text { dgeable about the cou } \\
\text { nd nature of instruction }\end{array}$ & SA & A & $\mathrm{D}$ & SD & $\mathrm{NA}$ \\
\hline 25 & $\begin{array}{l}\text { Our counseling department tends to advise students, } \\
\text { regardless of future college or work plans, to consider } \\
\text { enrolling agricultural education. }\end{array}$ & SA & A & $\mathrm{D}$ & SD & $\mathrm{NA}$ \\
\hline 26 & $\begin{array}{l}\text { If a college bound student expresses interest in an } \\
\text { agricultural education course our guidance department } \\
\text { tends to advise him/her to enroll. }\end{array}$ & SA & A & $\mathrm{D}$ & SD & $\mathrm{NA}$ \\
\hline 27 & $\begin{array}{l}\text { Student IEP's are an accurate reflection of the } \\
\text { students' abilities and desires. }\end{array}$ & SA & A & $\mathrm{D}$ & SD & $\mathrm{NA}$ \\
\hline 28 & $\begin{array}{l}\text { Agricultural teachers have success with students with } \\
\text { disabilities. }\end{array}$ & SA & $\mathrm{A}$ & $\mathrm{D}$ & SD & $\mathrm{NA}$ \\
\hline 29 & $\begin{array}{l}\text { FFA membership should be required of every } \\
\text { agricultural student. }\end{array}$ & SA & A & D & SD & NA \\
\hline
\end{tabular}




\begin{tabular}{|c|c|c|c|c|c|c|}
\hline 30 & $\begin{array}{l}\text { Agricultural teachers have higher expectations for their } \\
\text { students than regular education teachers. }\end{array}$ & SA & $\mathrm{A}$ & $\mathrm{D}$ & SD & $\mathrm{NA}$ \\
\hline 31 & $\begin{array}{l}\text { Agricultural teachers should be included in the } \\
\text { scheduling process of their current students. }\end{array}$ & SA & A & $\mathrm{D}$ & SD & $\mathrm{NA}$ \\
\hline 32 & $\begin{array}{l}\text { Agricultural classes are a place for students to learn } \\
\text { skills that they can use in the future. }\end{array}$ & SA & $\mathrm{A}$ & $\mathrm{D}$ & SD & $\mathrm{NA}$ \\
\hline 33 & $\begin{array}{l}\text { Agricultural classes are a place for students to relax } \\
\text { from the pressures of the regular class requirements } \\
\text { but still learn new skills. }\end{array}$ & SA & $\mathrm{A}$ & D & SD & $\mathrm{NA}$ \\
\hline 34 & $\begin{array}{l}\text { Agricultural education teachers are good at modifying } \\
\text { program content for students with modifications listed } \\
\text { in their IEP's. }\end{array}$ & SA & A & $\mathrm{D}$ & SD & $\mathrm{NA}$ \\
\hline 35 & $\begin{array}{l}\text { Your schools agricultural education teacher has all the } \\
\text { needed equipment to conduct a quality program. }\end{array}$ & SA & $\mathrm{A}$ & D & SD & $\mathrm{NA}$ \\
\hline 37 & $\begin{array}{l}\text { Students with learning disabilities must be enrolled in } \\
\text { some career and technical education class to motivate } \\
\text { them to graduate high school. }\end{array}$ & SA & A & $\mathrm{D}$ & SD & $\mathrm{NA}$ \\
\hline 38 & $\begin{array}{l}\text { Students with learning disabilities are enrolled in } \\
\text { agricultural education to give them a positive adult role } \\
\text { model. }\end{array}$ & SA & $\mathrm{A}$ & D & SD & $\mathrm{NA}$ \\
\hline 39 & $\begin{array}{l}\text { Career and technical education programs are funded } \\
\text { based on the number of completers, testing statistics, } \\
\text { and job placements. }\end{array}$ & SA & $\mathrm{A}$ & $\mathrm{D}$ & SD & $\mathrm{NA}$ \\
\hline 40 & $\begin{array}{l}\text { Special education students perform as well in } \\
\text { agricultural education classes as they do in core } \\
\text { curriculum classes. }\end{array}$ & SA & A & $\mathrm{D}$ & SD & NA \\
\hline 41 & Students' interests and goals change each year. & SA & A & $\mathrm{D}$ & SD & $\mathrm{NA}$ \\
\hline 42 & $\begin{array}{l}\text { Students should be given an interest survey each year } \\
\text { before scheduling. }\end{array}$ & SA & A & D & SD & NA \\
\hline 43 & $\begin{array}{l}\text { Agricultural education develops premier leadership in } \\
\text { all students. }\end{array}$ & SA & A & $\mathrm{D}$ & SD & $\mathrm{NA}$ \\
\hline 44 & $\begin{array}{l}\text { Agricultural education develops career interests in all } \\
\text { students. }\end{array}$ & SA & A & $\mathrm{D}$ & SD & $\mathrm{NA}$ \\
\hline 45 & $\begin{array}{l}\text { Agricultural education teachers use a variety of } \\
\text { teaching techniques. }\end{array}$ & SA & $\mathrm{A}$ & $\mathrm{D}$ & SD & $\mathrm{NA}$ \\
\hline 46 & $\begin{array}{l}\text { Students who are successful in a agricultural education } \\
\text { class are successful in their core curriculum classes. }\end{array}$ & SA & $\mathrm{A}$ & $\mathrm{D}$ & SD & $\mathrm{NA}$ \\
\hline
\end{tabular}


Instructions: Please rank the following statements in order from 1 to 5 with what you feel is the most important reasons for scheduling students into agricultural education programs. With 1 being the highest and 5 being the lowest:

47. I feel the most important reasons to schedule students into agricultural education programs are because

$\begin{array}{cl}\text { a. } & \text { students are interested in the subject } \\ \text { b. } & \text { students can become completers in the area } \\ \text { c. } & \text { students can earn edge credits } \\ \text { d. } & \text { students have heard positive things about the instructor } \\ \text { e. } & \text { it fits in their schedule }\end{array}$

48. Agricultural teachers are most concerned with

a. Student agricultural achievement and personal growth

b. Chapter success

c. Student learning CSO's material

d. School involvement in the community

e. Student total school and community achievement and

involvement

49. Students with disabilities succeed in high school because

a. There IEP's properly reflect their needs and levels

b. They are in classes with teachers that keeps them interested

c. There parents are more actively involved in their education than other students

d. They have outlets to use when they are in trouble unlike regular education students (resource rooms, special education services etc.)

e. They are filtered into classes with teachers that are known to work with special education students better than other teachers

Instructions: Please read each question completely and place a checkmark in front of the appropriate response or provide an answer where indicated.

50. What is your gender?

a. Male

b. Female

51. How long have you been employed in your present position?

$\begin{array}{cl}\text { a. } & 0-5 \text { years } \\ \text { b. } & 6-10 \text { years } \\ \text { c. } & 11-15 \text { years } \\ \text { d. } & 16-20 \text { years } \\ \text { e. } & \text { over } 20 \text { years }\end{array}$


52. How would you define your ethnic groups(s)?

$\begin{array}{ll}\text { a. } & \text { American Indian or Alaskan Native } \\ \text { b. } & \text { Asian or Pacific Islander } \\ \text { c. } & \text { Black } \\ \text { d. } & \text { Hispanic } \\ \text { e. } & \text { White }\end{array}$

53. How would you describe where you grew up?

a. On a farm or ranch

b. In a city

c. In a suburb

d. In a rural area not on a farm

54. What is your age?

$\begin{array}{cl}\text { a. } & >25 \text { years } \\ \text { b. } & 25-35 \text { years } \\ \text { c. } & 35-45 \text { years } \\ \text { d. } & 45-55 \text { years } \\ \text { e. } & <55 \text { years }\end{array}$

55. Were you enrolled as a high school student in an agricultural education program?

a. Yes

b. No

c. Not offered at my high school

56. Were you enrolled in 4-H as a youth?

a. Yes

b. No

57. How many students do you have in your school with IEP's?

$\begin{aligned} \text { a. } & <100 \\ \text { b. } & 100-250 \\ \text { c. } & 250-500 \\ \text { d. } & >500\end{aligned}$

58. Based on the WVSSAC school size ranking, what size is your school?

a. A

b. $\quad \mathrm{AA}$

c. AAA

d. AAAA 
59. What agricultural course concentrations does your school offer? (Check all that apply.)

\begin{tabular}{cl} 
a. & Food Products and Processing Systems \\
b. & Plant Systems \\
c. & Animal Systems \\
d. & Power Structural and Technical Systems \\
e. & Natural Resource Systems \\
f. & Environmental Service Systems \\
g. & Agribusiness Systems \\
\hline h. & Do not know
\end{tabular}

60. How many agricultural teachers does your school employee?

Comments:

\section{Thank you for taking the time to complete this Questionnaire!}

If you have any questions regarding the questionnaire, please contact me at: nriggle@mix.wvu.edu 